\title{
BUHLIV BEDS (NEOGENE, MIOCENE) OF THE PODILLYA (WESTERN UKRAINE): MICROPALEONTOLOGICAL, STRATIGRAPHICAL, FACIAL, PALEOECOLOGICAL, PALEOGEOGRAPHICAL DIAGNOSTIC CRITERIA AND FORMATION CONDITIONS
}

\section{Tuzyak Ya. M.}

\section{INTRODUCTION}

Since the allocation of the Buhliv beds by V.D. Laskarev in $1897^{1}$ the question of volume, age affiliation, stratigraphic position, distribution, facial analogues and their use, in general, as a stratigraphical unit, remain debatable and completely outstanding ${ }^{2}$. They are widely distributed not only in the territory of Western Ukraine (Central Paratethys), their analogues are known outside it - Europe, Moldova (Central Paratethys), Southern Ukraine, Transcaucasia, Turkmenistan, etc. (Eastern Paratethys). For a long time this straton was a volume of active discussion in the works of domestic and foreign researchers, it led to the holding of the All-Union Colloquium ${ }^{2}$ and decision-making regarding the Buhliv beds, in particular their use as a stratigraphical unit for practical stratigraphy.

The aim of the study is to clarify the scientific, applied, cultural, educational and environmental significance of the Buhliv beds, to solve discussion issues, to study the systematic composition of microfossils in order to determine the criteria of dating and stratigraphical position in the RSS (ICH), genesis conditions, to assess paleogeographical and paleoecological features of the environment for the construction of differentrank geological models.

In order to realize the goal, the results of more than 100 years of study of the Buhliv beds and evolution of the views of researchers (from the moment

1 Ласкарев В.Д. О сарматских отложениях, некоторых мест Волынской губернии. Зап. Новорос. о-ва естествоиспытателей. 1897. № 21. Вып. 2. С. 89-115.

Бугловские слои миоцена : Материалы Всесоюзного симпозиума. Львов 6-16 сентября 1966 г. Киев : Наук. думка, 1970. 279 с.

Венглинский И.В., Горецкий В.А. Стратотипы миоценовых отложений ВолыноПодольской плиты, Предкарпатского и Закарпатского прогибов. Киев : Наук. думка, $1979.176 \mathrm{c}$.

Кульчицкий Я.О., Кульчицкий А.Я. Двустворчатые и брюхоногие моллюски из сармата Предкарпатского и Закарпатского прогибов и их стратиграфическое значение. Палеонтол. сборник. 1983. № 20. С. 50-58.

Приходько М.Г., Пономарьова Л.Д. Гелогічна будова Закарпатського прогину. Моногрфія. Київ : УкрДГРІ, 2018. 84 с. 
to today $)^{3}$ were analyzed, as well as the results of their own ${ }^{4}$ scientific field and laboratory studies (in particular microfossils) to determine the systematic composition and degree of preservation of fossil material for solving problem issues.

Therefore, before drawing conclusions and making recommendations on this stratigraphic unit to achieve the goal, a number of tasks have been accomplished, among which the main ones are:

1. Analysis of primary views and list of criteria for the allocation of these layers by V.D. Laskarev in accordance with priority rules in stratigraphy and paleontology.

2. An overview of the evolution of views of different generations of geologists regarding the Buhliv beds over the more than 100-year history of research, identifying problematic discussion issues.

3. Analysis of the author's views on the Buhliv beds adopted at the AllUnion Colloquium on Tours to the sections of Volhyn ${ }^{5}$ and their supporters.

4. Based on preliminary studies of the author's microfossils (on the example of the Vanzhuliv village section, Ternopil region) to establish criteria for the boundaries of these beds, to determine the volume, to justify age affiliation, to identify facial analogues and geographical distribution, to

3 Бугловские слои миоцена: Материалы Всесоюзного симпозиума. Львов 6-16 сентября 1966 г. Киев : Наук. думка, 1970. 279 с.

Венглинский И.В., Горецкий В.А. Стратотипы миоценовых отложений ВолыноПодольской плиты, Предкарпатского и Закарпатского прогибов. Киев : Наук. думка, 1979. $176 \mathrm{c.}$

Кульчицкий Я.О.. Кульчицкий А.Я. Двустворчатые и брюхоногие моллюски из сармата Предкарпатского и Закарпатского прогибов и их стратиграфическое значение. Палеонтол. сборник. 1983. № 20. С. 50-58.

Москалюк К.Л. Аналіз рельєфу Подільських Товтр для оптимізації природокористування : автореф. ... канд. географ. наук : 11.00 .04 «Геоморфологія і палеогеографія». Львів, 2009. 23 с.

${ }^{4}$ Тузяк Я. Баденій-сарматська регіональна подія зникнення як критерій для проведення границі в межах Поділля. Розвиток промисловості та суспільства. Секція 5. Геологія та прикладна мінералогія. 22-24 травня 2019 р. Матеріали конференції. Кривий Ріг, 2019. С. 44-48.

Тузяк Я. Буглівські верстви (міоцен, неоген) Тернопільської області комплексна геологічна пам'ятка природи: стан охорони i перспективи рекреаційного використання. Мінерально-сировинні багатства Украӥни: иляхи оптимального використання. Матеріали восьмої науково-практичної конференції, 4 жовтня 2019 р. смт Хорошів. Київ, 2019. С. 122-132.

Тузяк Я. Границя баденію/сармату (неоген, міоцен): проблеми і критерії проведення (на прикладі розрізу с. Ванжулів Тернопільської обл.). Актуальні проблеми та перспективи розвитку геологіï: наука й виробництво. Матеріали VI Міжнародного геологічного форуму, 17-22 червня 2019 р., м. Одеса, Україна. Київ : УкрДГРІ, 2019. С. 218-221.

Тузяк Я. Подія на границі баденій/сармат в межах Поділля: палеогеографічні та палеоекологічні зміни в Центральному Паратетисі. Здобутки та перспективи розвитку геологічної науки в Україні: збірник тез наукової конференції, присвяченої 50-річчю Інституту геохімії, мінералогії та рудоутворення імені М.П. Семененка, Київ, 14-16 травня 2019 р. У 2-х томах. НАН України, Ін-т геохімії, мінералогії та рудоутворення ім. М.П. Семененка. Київ, 2019. Т. 2. С. 229-231.

Бугловские слои миоцена : Материалы Всесоюзного симпозиума. Львов 6-16 сентября 1966 г. Киев : Наук. думка, 1970. 279 с. 
establish analogues of these beds in other territories, to provide evidence regarding the refusal or abandonment of Buhliv beds as a stratigraphical unit, to clarify stratigraphical provisions in the RSS, to compare with the units of the ICC, to characterize perceptions about paleogeographical and paleoecological environment formation.

\section{The significance of learning Buhliv beds}

The study of Bugliv beds has scientific and applied, cultural and educational, environmental significance (Fig. 1). Scientific and applied is to solve issues at the local and regional levels. The local level covers the consideration of them as transitional basal beds of Late Badenian/Sarmatian within Podillya. The regional is to define the criteria and evaluate them for carrying out the Badenian/Sarmatian boundary in Central Paratethys; using them as a stratigraphical unit in the construction of diverse geological environment models. Cultural and educational has the purpose of considering them as an object of geological heritage (in 1983 the natural exposure of the Ogryshkivtsi village received the status of a geological monument of nature of local importance and was included in the register of natural reserve fund of Ternopil region). Environmental protection consists in the preservation of unique and unique ecosystems, which belong at the same time to both objects of protection and preservation, as well as to resources for the development of recreation and tourism, organization of scientific research and ecological-educational activities. On the geoturistic potential of the Buhliv beds as a complex geological monument of nature, the state of protection and prospects of recreational use are covered in the author's article 6 .

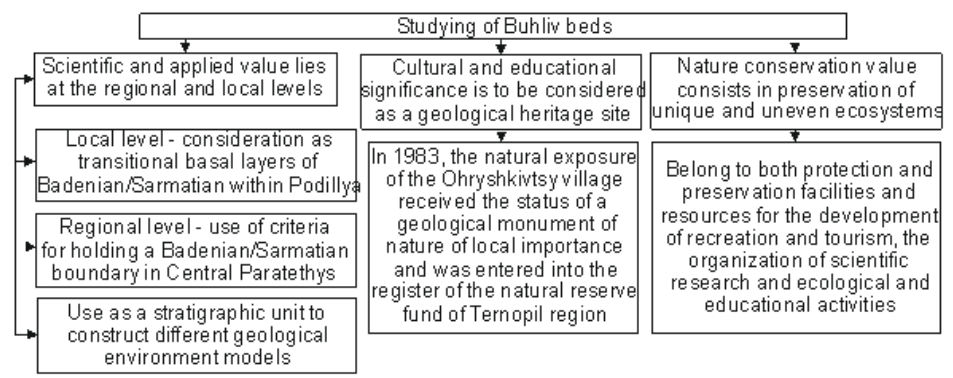

\section{Fig. 1. Model of scientific-applied, cultural-educational and environmental importance of Buhliv beds}

\footnotetext{
6 Тузяк Я. Буглівські верстви (міоцен, неоген) Тернопільської області комплексна геологічна пам'ятка природи: стан охорони i перспективи рекреаційного використання. Мінерально-сировинні багатства Украӥни: иляхи оптимального використанняю Матеріали восьмої науково-практичної конференції, 4 жовтня 2019 р. смт Хорошів. Київ, 2019. С. 122-132.
} 


\subsection{Geological setting}

The Miocene deposits of the study area were paleogeographically formed under the conditions of the peripheral north-eastern part of Central Paratethys, located on the boundary of the connection with Eastern Paratethys (Fig. 2). Geotectonically, the Ukrainian segment of the Central Paratethys occupied the area of connection of the Carpathian Foredeep (a fragment of the AlpineHimalayan folding belt) with the south-western edge of the East European Platform. The result of the Miocene sedimentation is the build-up of the sedimentary cover within such structurally - tectonic elements as the Precarpathian Foredeep and the Volhyno-Podillya plate.

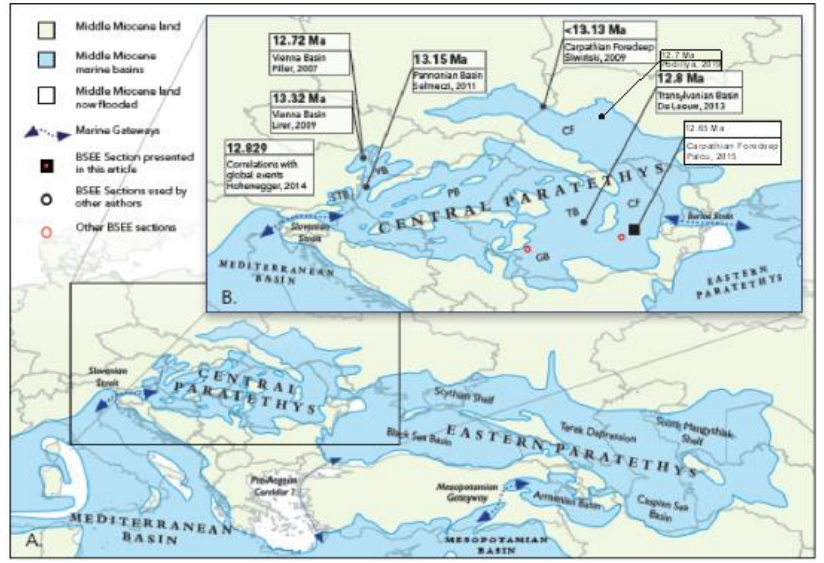

\section{Fig. 2. Paleogeographic model of Paratethys basins and age model of Badenian/Sarmatian Extinction Event (BSEE) by Palcu D.V. et al. ${ }^{7}$ with additions of the author}

Taking into account the position of this basin within Western Ukraine, the main controlling factors of its evolution and features of sedimentation were the character of the preneogenic (Meso-Cenozoic) foundation, the intensity of erosion, the energy of the aquatic environment, the presence of newly formed structures (reef and biohermic hills of the Medobory and Toutras) and local tectonic-magmatic activization (Fig. 19). In the history of basin evolution, an erossion (regressive) event is recorded at the boundary of Late Badenian/Early Sarmatian on a regional event (Tab. 4) with new transgretion in Sarmatian, so important regional external deposition control

7 Palcu D.V., Tulbure M., Bartol M., Kouwenhoven T.J., Krijgsman W. The Badenian-Sarmatian Extinction Event in the Carpathian foredeep basin of Romania: paleogeographic changes in the Paratethys domain. Global and Planetary Change. 2015. 36 p. DOI: 10.1016/j.gloplacha.2015.08.01. 
factors should be taken into account, including an intermittent opening and closing of sea ways between the Mediterranean/Indo-Pacific basins and Eastern Paratethys, caused by tectonic movements in the Carpathians belt, the orogenic stage of which is Sarmatian-Panonian, as evidenced by the intense manifestation of volcanic activity in the Transcarpathian foredeep (Fig. 3) ${ }^{8}$.

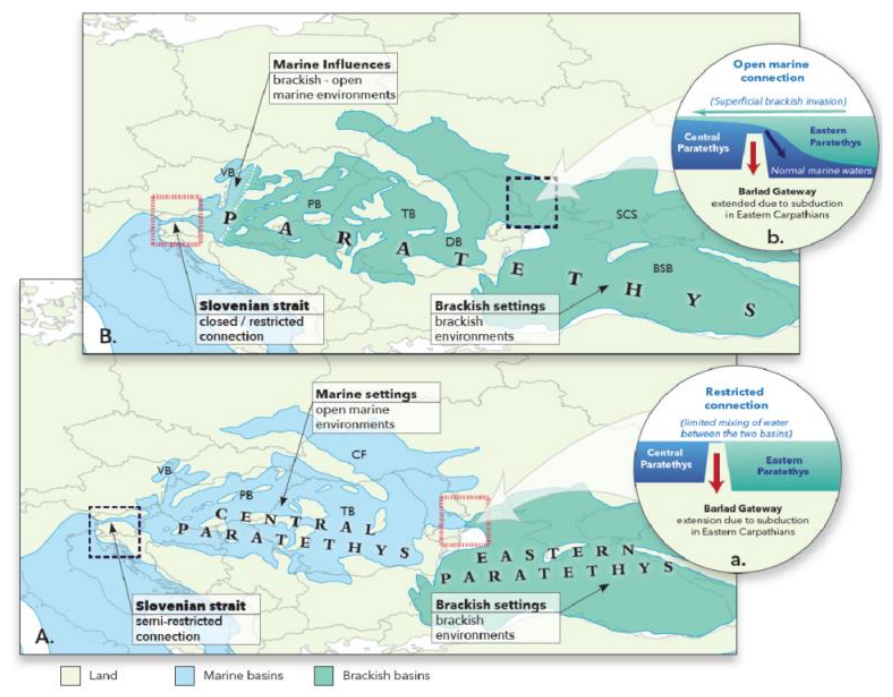

\section{Fig. 3. Central Paratethys model of interbasial ties with Mediterranean and Eastern Paratethys by Lirer F. et al. ${ }^{9}$}

The Middle Miocene sedimentation has local differences and is characterized by the manifestation of a complex of distinctive lithogenic-biostratigraphic features, but in general fits into the overall picture of the evolution of the territories belonging to the Central Paratethys, that is, it is clearly regional in nature and appears in the literature under the name Badenian-Sarmatian

\footnotetext{
${ }^{8}$ Приходько М.Г., Пономарьова Л.Д. Гелогічна будова Закарпатського прогину. Моногрфія. Київ : УкрДГРІ, 2018. 84 с.

Lirer F. et al. Astronomically forced teleconnection between Paratethyan and Mediterranean sediments during the Middle and Late Miocene. Palaeogeography, Palaeoclimatology, Palaeoecology. 2009. № 275(1-4). P. 1-13. DOI 10.1016/j.palaeo.2009.01.006

9 Lirer F. et al. Astronomically forced teleconnection between Paratethyan and Mediterranean sediments during the Middle and Late Miocene. Palaeogeography, Palaeoclimatology, Palaeoecology. 2009. № 275(1-4). P. 1-13. DOI 10.1016/j.palaeo.2009.01.006
} 
Extension Event (BSEE) ${ }^{10}$ is a marker (hiatus, erosion regressive boundary), which is characterized by the disappearance of typical marine forms - planktic foraminifers, radiolarians, corals, sea urchins. This was also noted by V.D. Laskarev in his monograph ${ }^{11}$. It can be traced in all regions of Central Paratethys and is correlated with the Konko-Volhynian border of Eastern Paratethys ${ }^{12}$.

Paratethys (the term introduced by V.D. Laskarev in 1924$)^{13}$ has been a system of sedimentary residual basins (Fig. 2) since the time of Oligocene, the development of which depended on the change of tectonic regimes. It extended from the coast of the Mediterranean Sea (areas of the Alpine foothills) in the West, Central Europe (areas of the Balkans, Transcarpathian and Precarpatian) to inland Asia (Black, Caspian and Aral Seas). The isolation of Central Paratethys from the world ocean resulted in the collision between the AfricanArabian and Euro-Asian tectonic plates and the formation of mountain structures of the Alpine-Himalayan fold belt. The manifestation of geodynamic processes (collision, subduction, orogenesis, tectonic-magmatic activation, formation of fault-folding structures) at the end of the Paleogen - at the beginning of the Neogene contributed to the formation of three separate paleogeographic units: Western (Alpine), Central (Carpathian-Balkan) and Eastern (Crimean-Caucasus) Paratethys. The long-existing western Paratethys, compiled by the Pre-Alpine basins of France, Switzerland, Southern Germany and Upper Austria ${ }^{14}$ disappeared until the end of the early Miocene. Central Paratethys occupied the territory of modern Central Europe and lasted from the Middle Miocene to the

10 Тузяк Я. Баденій-сарматська регіональна подія зникнення як критерій для проведення границі в межах Поділля. Розвиток промисловості та суспільства. Секція 5. Геологія та прикладна мінералогія. 22-24 травня 2019 р. Матеріали конференції. Кривий Ріг, 2019. С. 44-48.

Тузяк Я. Подія на границі баденій/сармат в межах Поділля: палеогеографічні та палеоекологічні зміни в Центральному Паратетисі. Здобутки та перспективи розвитку геологічної науки в Україні : збірник тез наукової конференції, присвяченої 50-річчю Інституту геохімії, мінералогії та рудоутворення імені М.П. Семененка, Київ, 14-16 травня 2019 р. У 2-х томах. НАН України, Ін-т геохімії, мінералогії та рудоутворення ім. М.П. Семененка. Київ, 2019. Т. 2. С. 229-231.

Palcu D.V., Tulbure M., Bartol M., Kouwenhoven T.J., Krijgsman W. The BadenianSarmatian Extinction Event in the Carpathian foredeep basin of Romania: paleogeographic changes in the Paratethys domain. Global and Planetary Change. 2015. 36 p. DOI: 10.1016/j.gloplacha.2015.08.01

Л1 Ласкарев В.Д. Фауна бугловских слоев Волыни. Санкт-Петербург, 1903. 126 с. (Тр. Геол. ком. Нов. сер. Вып. 5).

${ }_{12}$ Popov S.V., Shcherba I., Ilyina L., Nevesskaya L., Paramonova N., Khondkarian S., Magyar I. Late Miocene to Pliocene palaeogeography of the Paratethys and its relation to the Mediterranean. Palaeogeography, Palaeoclimatology, Palaeoecology. 2006. № 238 (1-4). P. 91-106. DOI: 10.1016/j.palaeo.2006.03.020

Popov S.V. et al. Eastern Paratethys stratigraphic scale of Neogene: correlation possibilities. Abstr. 14th RCMNS congress, 8-12 September 2013, Istanbul (Turkey).

3 Palcu D.V., Tulbure M., Bartol M., Kouwenhoven T.J., Krijgsman W. The

Badenian-Sarmatian Extinction Event in the Carpathian foredeep basin of Romania: paleogeographic changes in the Paratethys domain. Global and Planetary Change. 2015. 36 p. DOI: 10.1016/j.gloplacha.2015.08.01

${ }^{14}$ Senes J. Paläogeographie des Westkarpatischen Raumes in Beziehung zur übrigen Paratethys im Miozän. Geologické Práce. 1961. № 60. P. 1-56. 
Pliocene ${ }^{15}$. Eastern Paratettys covered the territory of modern Black, Caspian and Aral seas ${ }^{16}$, existed with Oligocene, relics of it still survived.

The periodic fragmentation of Paratethys and the subsequent isolation of individual basins contributed to the development of endemic biota, the results of which led to the allocation of regional chronostratigraphic units in their territories (Fig. 4), which made it difficult to compare biostratigraphic chrones with units of the standard geological time scale ${ }^{17}$.

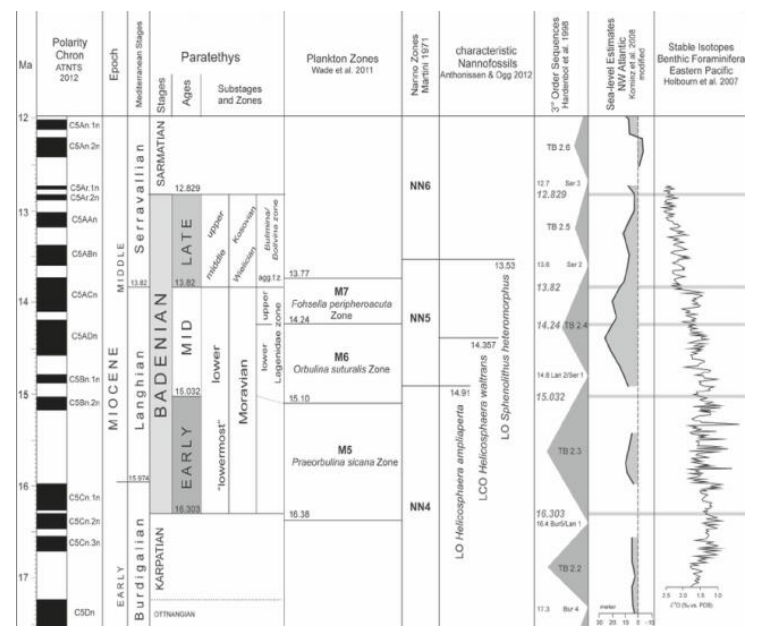

Fig. 4. Summary scale of dismemberment and correlation of chronostratigraphycal subdivisions of global (Mediterranean) and regional (Paratethian) levels with magnetochrones, biochrones (planktic foraminifers and calcareous nannofossils), sequels of eustatic sea level change (North-West Atlantic) and results of stable isotopes of oxygen (Eastern Tropical Pacific) by Hohenegger J. et al., 2014 ${ }^{18}$

\footnotetext{
${ }^{15}$ Cicha I., Seneš J. Sur la position du Miocene de la Paratcthys Central dans les cadre du Tertiaire de l'Europe. Geologicky Sbornik. 1968. № 19(1). P. 95-116.

Palcu D.V., Tulbure M., Bartol M., Kouwenhoven T.J., Krijgsman W. The BadenianSarmatian Extinction Event in the Carpathian foredeep basin of Romania: paleogeographic changes in the Paratethys domain. Global and Planetary Change. 2015. 36 p. DOI: 10.1016/j.gloplacha.2015.08.01

${ }^{16}$ Popov S.V., Shcherba I., Ilyina L., Nevesskaya L., Paramonova N., Khondkarian S., Magyar I. Late Miocene to Pliocene palaeogeography of the Paratethys and its relation to the Mediterranean. Palaeogeography, Palaeoclimatology, Palaeoecology. 2006. № 238 (1-4). P. 91-106, DOI:10.1016/j.palaeo.2006.03.020

${ }^{17}$ Hohenegger J., Corić S., Wagreich M. Timing of the Middle Miocene Badenian Stage of the Central Paratethys. Geologica Carpathica. February 2014. 65. 1. P. 55-66. DOI: $10.2478 /$ geoca-2014-0004.

${ }^{\text {is }}$ Hohenegger J., Corić S., Wagreich M. Timing of the Middle Miocene Badenian Stage of the Central Paratethys. Geologica Carpathica. February 2014. 65. 1. P. 55-66. DOI: $10.2478 /$ geoca-2014-0004.
} 

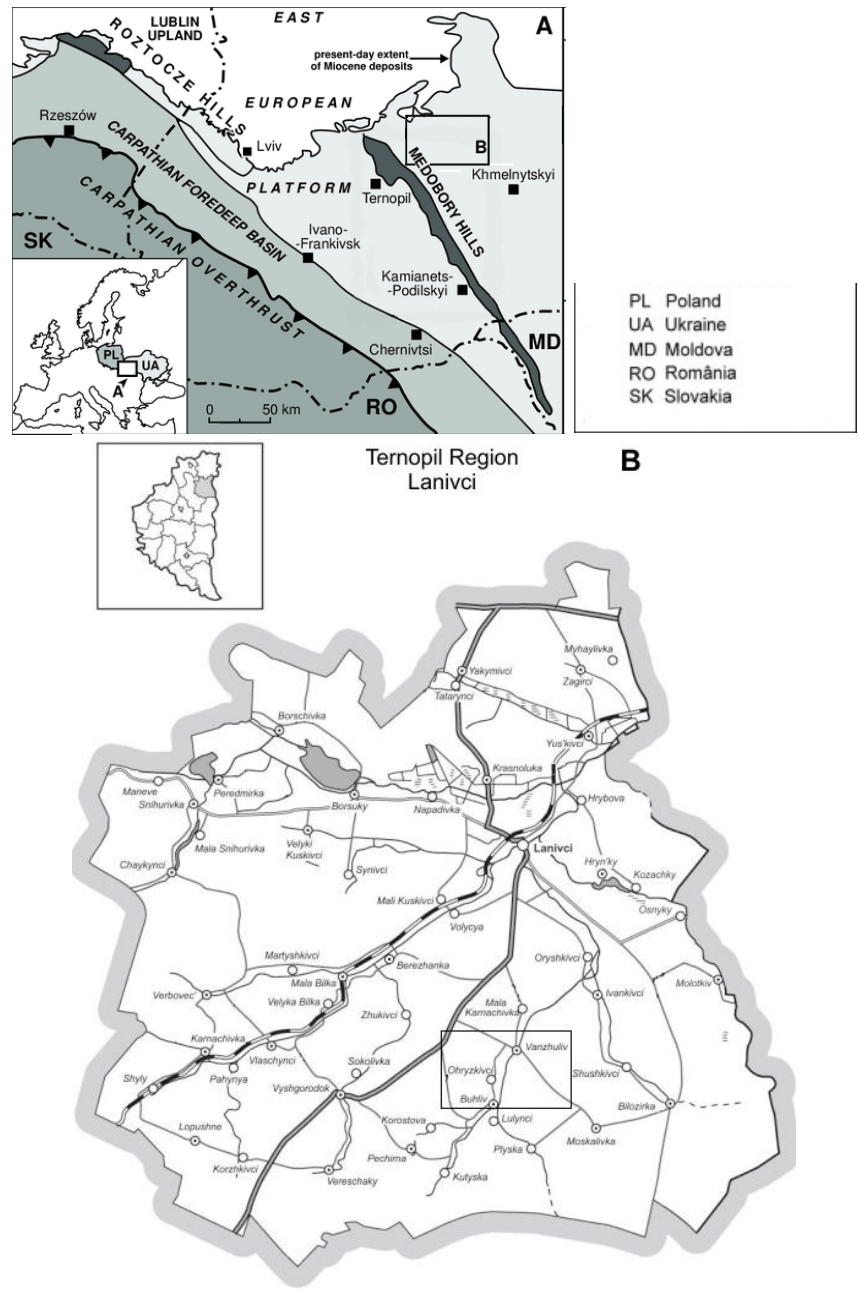

Fig. 5. Map of bioprovinces of Central Parathetis fragment within central Europe (Poland, Slovakia, Hungary, Ukraine, Moldova) by Rögl, Steininger, $1983^{19}$ (paleogeographic and tectonic position of the sections of the Buhliv beds)

${ }^{19}$ Rögl F., Steininger F.F. Vom Zerfall der Tethys zu Mediterran und Paratethys. Die Neogene Palaeogeographie und Palinspastik des zirkummediterranen Raumes. Annales Naturhistorischen Museum Wien. 1983. № 85. P. 135-163. 


\subsection{Material and methods}

The object of the research is a section of the Neogen (Miocene) Vanzhuliv village, located within Podillya (Ternopil region, Western Ukraine) (Fig. 5). The photography of the microfossils was carried out in the laboratory of the PAN Institute of Geological Sciences (Krakiw, Poland) using the Zeiss axiolab microscope Sony-S75 and camera Zeiss axioscope 40 Canon EOS SDS.

From the accumulated organogenic-detrital bed (Fig. 39), microfossills foraminifers, corals, dwarf molluscs (gastropods, bivalves, scaphopods), ostracodes, bryozoans, serpulids - have been studied by a biostratigraphic method. The studies were carried out according to the following scheme (Fig. 6). Systematic composition analysis with definition of transit forms was carried out in the detected complexes (transition from Badenian (or more ancient) to Sarmatian), updated complexes (first appearance of Sarmatian taxa), quantitative ratio of sculptured (ornamented) and smooth-walled taxa in fossil associations, size of taxa, degree of preservation (recrystallization of the mineral composition of the skeletons wall (limonitized, phosphatized), wall thickness (thin-walled transparent, translucent, thick-walled - opaque), degrees of destruction (mechanical damages), filling cavities of remains with rock.

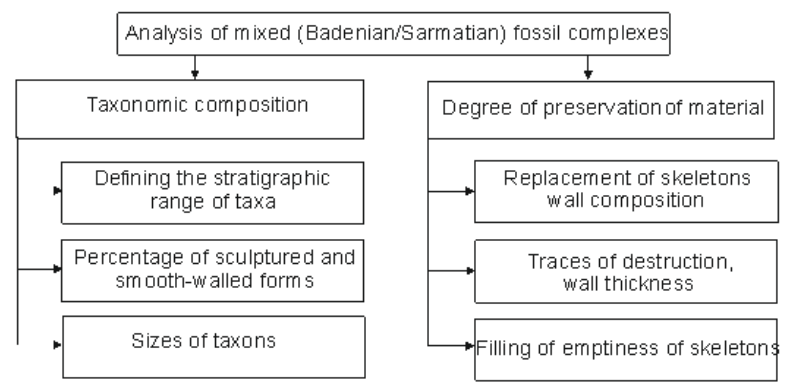

Fig. 6. Scheme for analysis of fossil material

\section{Paleontology}

The analysis of the works of domestic and foreign researchers on the systematic composition of fossils of Buhliv beds and their analogues was carried out (Tab. 1) within the territories belonging to Central Paratethys (Ukraine, Poland, Slovakia, Austria, Croatia, Moldova, Romania) (Fig. 5). At the present stage, the systematic composition of molluscs (gastropods and bivalves) has been studied in detail from the Buhliv beds of Ukraine ${ }^{20}$. The results of studies of other groups of organisms are covered sporadically in separate works.

20 Ласкарев В.Д. О сарматских отложениях, некоторых мест Волынской губернии. Зап. Новорос. о-ва естествоиспытателей. 1897. № 21. Вып. 2. С. 89-115.

Ласкарев В.Д. Фауна бугловских слоев Волыни. Санкт-Петербург, 1903. 126 с. (Тр. Геол. ком. Нов. сер. Вып. 5). 
Review of the systematic composition of fossil organisms of Buhliv beds and their analogues within Central Paratethys ${ }^{21}$

\begin{tabular}{|c|c|c|c|}
\hline Year & Author & Group of organisms & Conclusion about age \\
\hline \multicolumn{4}{|c|}{ Ukraine, Poland } \\
\hline 1897,1903 & Laskarev & $\begin{array}{l}\text { Molluscs (gastropods } \\
\text { and bivalves) }\end{array}$ & Early Sarmatian \\
\hline 1904 & Lomnitskyi & Molluscs & $\begin{array}{l}\text { Mixed complexes Badenian- } \\
\text { Sarmatian }\end{array}$ \\
\hline 1934 & Böm & Molluscs & $\begin{array}{l}\text { Mixed complexes Badenian- } \\
\text { Sarmatian }\end{array}$ \\
\hline 1914 & Friedberg & Molluscs & $\begin{array}{l}\text { Mixed complexes Badenian- } \\
\text { Sarmatian }\end{array}$ \\
\hline 1932 & $\begin{array}{l}\text { Charnotskyi, } \\
\text { Kovalewskyi }\end{array}$ & Molluscs & $\begin{array}{c}\text { Mixed complexes Badenian- } \\
\text { Sarmatian }\end{array}$ \\
\hline 1970 & Krah & Molluscs & $\begin{array}{l}\text { Mixed complexes Badenian- } \\
\text { Sarmatian }\end{array}$ \\
\hline 1954 & Kudrin & $\begin{array}{l}\text { Molluscs (gastropods } \\
\text { and bivalves) }\end{array}$ & Early Sarmatian \\
\hline 1962 & Venglinskyi & Foraminifers & Early Sarmatian \\
\hline 1964 & Horetskyi & $\begin{array}{l}\text { Molluscs (gastropods } \\
\text { and bivalves) }\end{array}$ & Early Sarmatian \\
\hline 1964,1975 & Didkovskyi & Foraminifers & Early Sarmatian \\
\hline 1975 & $\begin{array}{l}\text { Horetskyi, } \\
\text { Venglinskyi }\end{array}$ & Foraminifers, molluscs & $\begin{array}{c}\text { Late Badenian - Early } \\
\text { Sarmatian }\end{array}$ \\
\hline 1967,1970 & Luchkowska & Foraminifers & Early Sarmatian \\
\hline 1965,1970 & $\begin{array}{c}\text { Vyalov, } \\
\text { Hryshkevich }\end{array}$ & Molluscs, foraminifers & Late Badenian \\
\hline 1983 & Kulchytskyi & Molluscs & Early Sarmatian \\
\hline 2016 & Prysyazhnyuk & Molluscs & Late Badenian \\
\hline 2012 & $\begin{array}{c}\text { Górka, } \\
\text { Studencka, } \\
\text { Jasionowski, } \\
\text { et al. }\end{array}$ & $\begin{array}{c}\text { Coralline algae, } \\
\text { foraminifers, bryozoans, } \\
\text { corals, molluscs, } \\
\text { echinoderms, crabs }\end{array}$ & Early Sarmatian \\
\hline 2012 & $\begin{array}{c}\text { Hara, } \\
\text { Jasionowski }\end{array}$ & Bryozoans & Early Sarmatian \\
\hline 2012 & $\begin{array}{c}\text { Peryt, } \\
\text { Jasionowski }\end{array}$ & Foraminifers & Early Sarmatian \\
\hline \multicolumn{4}{|c|}{ Moldova } \\
\hline 2011 & $\begin{array}{c}\text { Brânzilă, } \\
\text { Chirilă, Jitaru }\end{array}$ & $\begin{array}{c}\text { Foraminifers, } \\
\text { molluscs, ostrscods }\end{array}$ & Early Sarmatian \\
\hline \multicolumn{4}{|c|}{ Romania } \\
\hline 2008,2015 & $\begin{array}{l}\text { Filipescu, } \\
\text { Silye }\end{array}$ & Foraminifers & Early Sarmatian \\
\hline \multicolumn{4}{|c|}{ Slovakia } \\
\hline 2006 & $\begin{array}{c}\text { Fordinal, } \\
\text { Zágoršek, } \\
\text { Zlinská }\end{array}$ & $\begin{array}{l}\text { Foraminifers, } \\
\text { molluscs, ostrscods }\end{array}$ & Early Sarmatian \\
\hline
\end{tabular}


Continuation of Table 1

\begin{tabular}{|c|c|c|c|}
\hline Year & Author & Group of organisms & Conclusion about age \\
\hline \multicolumn{4}{|c|}{ Austria } \\
\hline 2009 & $\begin{array}{c}\text { Gebhardt, } \\
\text { Zorn, Roetzel }\end{array}$ & $\begin{array}{l}\text { Foraminifers, } \\
\text { ostrscods }\end{array}$ & Early Sarmatian \\
\hline \multicolumn{4}{|c|}{ Northern Croatia } \\
\hline 2006 & $\begin{array}{c}\text { Vrsaljko, } \\
\text { Pavelić, } \\
\text { Miknić, et al. }\end{array}$ & $\begin{array}{l}\text { Foraminifers, } \\
\text { ostrscods }\end{array}$ & Early Sarmatian \\
\hline
\end{tabular}

21 Ласкарев В.Д. О сарматских отложениях, некоторых мест Волынской губернии. Зап. Новорос. о-ва естествоиспытателей. 1897. № 21. Вып. 2. С. 89-115. Ласкарев В.Д. Фауна бугловских слоев Волыни. Санкт-Петербург, 1903. 126 с. (Тр. Геол. ком. Нов. сер. Вып. 5).

Королюк И.К. Подольские Толтры и vсловия их образования. Труды Ин-та геол. наук АН СССР. Сер. геол. 1952. Вып. 110. № 56. 120 с.

Кульчицкий Я.О.. Кульчицкий А.Я. Двустворчатые и брюхоногие моллюски из сармата Предкарпатского и Закарпатского прогибов и их стратиграфическое значение. Палеонтол. сборник. 1983. № 20. С. 50-58.

Бугловские слои миоцена: материалы Всесоюзного симпозиума. Львов 6-16 сентября 1966 г. Киев : Наук. думка, 1970. 279 с.

Венглинский И.В., Горецкий В.А. Стратотипы миоценовых отложений ВолыноПодольской плиты, Предкарпатского и Закарпатского прогибов. Киев : Наук. думка, $1979.176 \mathrm{c.}$

Королюк И.К. Подольские Толтры и условия их образования. Труды Ин-та геол. наук АН СССР. Сер. геол. 1952. Вып. 110. № 56. 120 с.

Присяжнюк В. О переходных слоях рр. Ушицы и Ушки В.Д Ласкарева. Materialete conferintei stiintifice nationale cu participare internationala „Mediul si Dezvoltarea durabila“. Editia a III-a consacrata aniversarii a 80 ani de la nasterea prof. univ., dr. hab. Alexandru Lungu. 06-08 octombrie 2016. P. 53-56.

Górka M., Studencka B., Jasionowski M., Hara U., Wysocka A., Poberezhskyy A. The Medobory Hills (Ukraine): Middle Miocene Reef Systems in the Parathetys, their biological diversity and lithofacies. Biuletyn Państwowego Instytutu Geologicznego. 2012. № 449. P. 147-174.

Hara U., Jasionowski M. The Early Sarmatian bryozoan Celleporina medoborensis sp. nov. from the Medobory reefs of west ern Ukraine (Central Paratethys). Geological Quarterly. 2012. 56 (4). P. 895-906.

Peryt D., Jasionowski M. Sarmatian foraminiferal assemblages of cavern fillings in the Badenian reefs of Medobory (Polupaniwka, Western Ukraine). Biuletyn Państwowego Instytutu Geologicznego. 2012. № 449. P. 175-184.

Brânzilă M., Chirilă G., Jitaru M. Micropalaeontologic content of the Sarmatian from Southern Moldavian platform - a Backbulge depozone. Acta Palaeontologica Romaniae. 2011. V. 7. P. 45-59.

Filipescu S., Silye L. New Paratethyan biozones of planktonic foraminifera described from the Middle Miocene of the Transylvanian Basin (Romania). Geologica Carpathica. December 2008. № 59. 6. P. 537-544.

Fordinal K., Zágoršek K., Zlinská A. Early Sarmatian biota in the northern part of the Danube Basin (Slovakia). Geologica Carpathica. April 2006. 57. 2. P. 123-130.

Gebhardt H., Zorn I., Roetzel R. The initial phase of the early Sarmatian (Middle Miocene) transgression. Foraminiferal and ostracod assemblages from an incised valley fill in the Molasse Basin of Lower Austria. Austrian Journal of Earth Sciences. Vol. 102/2. Vienna, 2009. P. 100-119.

Vrsaljko D., Pavelić D., Miknić M., Brkic M., Kovacic M., Hećimović I., HajekTadesse V., Avanić R., Kurtanjek N. Middle Miocene (Upper Badenian/Sarmatian) Palaeoecologv and Evolution of the Environments in the Area of Medvednica Mt. (North Croatia). Geologia Croatica. Zagreb. 2006. 59/1. P. 51-63. 


\subsection{Characteristic of the systematic composition of microfossils}

and criteria (signs) for the diagnosis of Badenian and Sarmatian forms

Foraminifers (Tab. 2, 3; Fig. 7).

The complex consists of agglutinated Miliolidae and Texularide (6 species), and calcium carbonate, represented by both benthic (30 species) and planktic forms ( 1 species of two generations). The most diverse and representative are the benthic, the leading place among which by the number of species, genus and taxa are miliolid. The leading place in the number of species, births and individuals is occupied by Miliolidae. Members of a number of Rotaliidae are represented by fewer taxa (except for the families Discorbidae, Cibicididae, Ammoniidae, Elphidiidae), which are characterized by a large number of individuals and species diversity. For systematics foraminifera used modern classification world database ${ }^{22}$.

Table 2

Systematic structure of foraminifera

\begin{tabular}{|c|c|c|c|c|}
\hline Order & Family & Genus & Deep, m & $\begin{array}{l}\text { Criteria (signs) for } \\
\text { the diagnostic of } \\
\text { Badenian and } \\
\text { Sarmatian forms } \\
\end{array}$ \\
\hline 1 & 2 & 3 & 4 & 5 \\
\hline Miliolida & Hauerinidae & Affinetrina & $50-60$ & \multirow{16}{*}{$\begin{array}{l}\text { Mass clusters } \\
\text { represented by } \\
\text { agglutinated ( } 2 \\
\text { species) and calcium } \\
\text { carbonate forms. The } \\
\text { main features of } \\
\text { Sarmatian (Fig. 7; } \\
\text { C, G) there is a large } \\
\text { size (more than 1 } \\
\text { mm) of taxa, } \\
\text { presence of ribbed } \\
\text { (ornamented) forms } \\
\text { (fine size, rare } \\
\text { (single)), degree: } \\
\text { good preservation of } \\
\text { skeletons. In } \\
\text { Badenian (Fig. 7; } \\
\text { C, G) there is a } \\
\text { replacement of the } \\
\text { skeleton } \\
\text { (limonitization), } \\
\text { traces of destruction } \\
\text { (mechanical } \\
\text { damages). }\end{array}$} \\
\hline & & Articularia & $50-60$ & \\
\hline & & Articulina & $50-60$ & \\
\hline & & Miliolinella & $50-60$ & \\
\hline & & Hauerina & $50-60$ & \\
\hline & & Pseudotriloculina & $50-60$ & \\
\hline & & Pyrgo & $0-50$ & \\
\hline & & Quinqueloculina & $0-50$ & \\
\hline & & Sigmoilinita & $95-100$ & \\
\hline & & Sigmoilopsis & $95-105$ & \\
\hline & & Sigmoinella & $0-50$ & \\
\hline & & Triloculina & $50-60$ & \\
\hline & & Varidentella & $50-60$ & \\
\hline & Fischerinidae & Nodobaculariella & $50-60$ & \\
\hline & Alveolinidae & Borelis & $50-60$ & \\
\hline & Spiroloculinidae & Spiroloculina & $50-60$ & \\
\hline
\end{tabular}

22 Hayward B.W., Le Coze F., Vachard D., Gross O. World Foraminifera Database. 2019. URL: http://www.marinespecies.org/aphia.php? $\mathrm{p}=$ taxdetails\&id=113497 on 2019-11-10. 
Continuation of Table 2

\begin{tabular}{|c|c|c|c|c|}
\hline 1 & 2 & $\mathbf{3}$ & 4 & 5 \\
\hline \multirow[t]{2}{*}{ Miliolana } & Peneroplidae & Peneroplis & $50-60$ & $\begin{array}{l}\text { Rare, Sarmatian } \\
\text { (Fig. 7; A). }\end{array}$ \\
\hline & & Spirolina & $50-60$ & $\begin{array}{l}2 \text { generation- } \\
\text { megaspherical } \\
\text { (Badenian) (Fig. 7; H) } \\
\text { and microspherical } \\
\text { (the last turn of the } \\
\text { spiral is straightened) } \\
\text { (Sarmatian) } \\
\text { (Fig. 7; B, D). }\end{array}$ \\
\hline \multirow[t]{2}{*}{ Textulariida } & Textulariidae & Textularia & 95-105 & \multirow[t]{2}{*}{ Rare (single). } \\
\hline & & Semivulvulina & $95-105$ & \\
\hline \multirow[t]{10}{*}{ Rotaliida } & Eponididae & Eponides & $50-55$ & \multirow{3}{*}{$\begin{array}{l}\text { Sarmatian forms } \\
\text { (Fig. 7; E) are large } \\
\text { in size, good } \\
\text { preservation, with } \\
\text { translucent skeletons. } \\
\text { Badenian (Fig. 7; K) } \\
\text { small, with traces of } \\
\text { limonitized. }\end{array}$} \\
\hline & Discorbidae & Discorbis & $45-50$ & \\
\hline & Discorbinellidae & Hanzawaia & $50-60$ & \\
\hline & Cibicididae & Cibicides & $30-100$ & \multirow[b]{2}{*}{$\begin{array}{l}\text { For Sarmatic forms } \\
\text { (Fig. 7; J, K) are } \\
\text { characterized by } \\
\text { translucent skeletons } \\
\text { larger than } 1 \mathrm{~mm} \text {. }\end{array}$} \\
\hline & & Lobatula & $40-55$ & \\
\hline & Nonionidae & Nonion & $50-55$ & $\begin{array}{l}\text { With traces of } \\
\text { limonitized (Fig. } 7 ; \mathrm{K} \text { ). }\end{array}$ \\
\hline & Melonidae & Melonis & $50-60$ & \multirow[b]{2}{*}{$\begin{array}{l}\text { Badenian (Fig. 7; G) } \\
\text { with traces of } \\
\text { mechanical damage, } \\
\text { small size, } \\
\text { limonitized. } \\
\text { Sarmatian (Fig. } 7 ; \text { G) } \\
\text { larger, good } \\
\text { preservation. }\end{array}$} \\
\hline & Pulleniidae & Pullenia & $30-55$ & \\
\hline & Ammoniidae & Ammonia & $50-55$ & $\begin{array}{l}\text { Badenian forms } \\
\text { (Fig. 7; E) smaller, } \\
\text { limonitized; } \\
\text { Sarmatian (Fig. 7; E) } \\
\text { are represented by } \\
\text { larger taxa, with } \\
\text { more chamber being } \\
\text { traced in the last turn. }\end{array}$ \\
\hline & Anomalinidae & Anomalinoides & $55-60$ & $\begin{array}{l}\text { It has a } \\
\text { biostratigraphic } \\
\text { value, a specie-index } \\
\text { for regions of Central } \\
\text { Paratethys (Fig. 7; } \\
\text { E, F). Rare forms of } \\
\text { good preservation } \\
\text { occur. }\end{array}$ \\
\hline
\end{tabular}


End of Table 2

\begin{tabular}{|c|c|c|c|c|}
\hline 1 & 2 & 3 & 4 & 5 \\
\hline & Elphidiidae & Elphidium & $0-55$ & $\begin{array}{l}\text { Badenian forms (Fig. } \\
7 ; \mathrm{K} \text { ) with traces of } \\
\text { replacement of } \\
\text { skeleton (limonitized, } \\
\text { phosphatized), small } \\
\text { size, non-keeled. } \\
\text { Sarmatian } \\
\text { (Fig. 7; K) - } \\
\text { appearance of keel, } \\
\text { size of taxa exceeds } 1 \\
\text { mm, good } \\
\text { preservation. }\end{array}$ \\
\hline & & Cribroelphidium & $50-55$ & \multirow{3}{*}{$\begin{array}{l}\text { Rare (single), good } \\
\text { preservation. }\end{array}$} \\
\hline & & Porosononion & $50-55$ & \\
\hline & Elphidiellidae & Elphidiella & $50-55$ & \\
\hline & Bolivinitidae & Bolivina & $30-105$ & Rare. \\
\hline & Globorotaliidae & Globorotalia & $100-200$ & $\begin{array}{l}\text { Represented by two } \\
\text { generations (6-8 } \\
\text { chamber and 9-11 } \\
\text { chambers of the final } \\
\text { whorl) - single. } \\
\text { Brittle skeletons. } \\
\text { Badenian keel (Fig. } \\
7 ; \text { I, N), a small size, } \\
\text { with fewer chambers } \\
\text { of the final whorl. } \\
\text { Sarmatian non-keeled } \\
\text { (Fig. 7; L, M), a large } \\
\text { size with more } \\
\text { chambers of the final } \\
\text { whorl. }\end{array}$ \\
\hline Rosalinida & Glabratellidae & Schackoinella & $55-60$ & $\begin{array}{l}\text { Rare (single). } \\
\text { Badenian small-sized } \\
\text { forms, with traces of } \\
\text { mechanical damage } \\
\text { (erased sculptural } \\
\text { elements), the } \\
\text { skeletons are opaque. }\end{array}$ \\
\hline
\end{tabular}

Below we give images of Buhliv beds foraminifera complexes (mixed type (different-age, different-facies). 


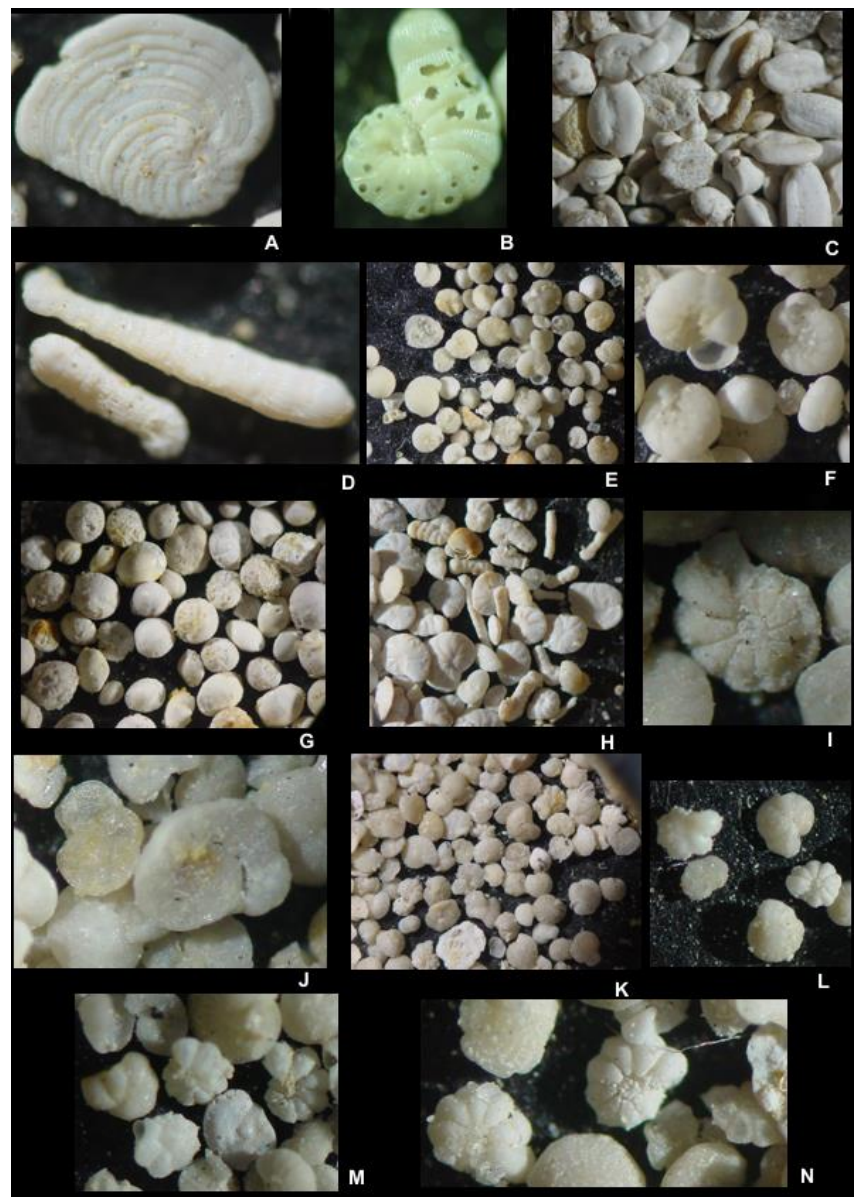

Fig. 7. A - benthic forms Peneroplis; B - mechanical damages on skeleton surface Spirolina; $\mathrm{C}$ - benthic agglutinated and calcium carbonate forms

Miliolida; D - benthic forms Miliolina (Spirolina); E - benthic forms Anomalinoides, Ammonia, Discorbis; $\mathbf{F}$ - benthic? forms Anomalinoides dividens; G - benthic forms Pyrgo, Pullenia; $\mathbf{H}$ - benthic forms Miliolina

(Spirolina); I, L, M, N, - planktic form Globorotalia menardi two generation: $\mathrm{L}, \mathrm{M}-6-8$ chamber; $\mathrm{I}, \mathrm{N}-\mathbf{9}-11$ chamber; $\mathrm{J}-$ benthic forms Lobatula lobatula; $\mathrm{K}$ - benthic and planktic forms Nonion, Cibicides, Lobatula, Elphidium, Globorotalia 
Paleoecological features. To characterize paleoecological living conditions foraminifer works have been used ${ }^{23}$. Quinqueloculina prefers a shallow marine environment $(0-50 \mathrm{~m})$ from desalinated lagoons to normally salty and hypersaline. They belong to epifauna, can lie freely on the bottom or attach to plants or sediment. Shallow, normally sea, accommodation deeps (2-65 m), in moderate and warm waters $\left(10-25^{\circ} \mathrm{C}\right)$ and a little increased salinity $(37-39 \%)$.

Keel Elphidium mainly herbivorous, concern the epifauna, they prefer sandy sediments and live in the shallow marine environment (the internal shelf) from warm to moderate and from normal to hyper-salty (35-70\%) waters. Elphidium aculetaum exists on tree seaweed and belongs to epifauna. Elphidium macellum is characterized by the same living conditions. The depth of water bodies is 0-20 m. The appearance of keel elphidiums is due to dense algae sprouts at the beginning of Early Sarmatian and the cause of morphological adaptation can be explained by the transition of the algae medium into plant sprouts. Anomalinidae (Anomalinoides, Cibicides) - belong to an epifauna, predominantly attached fixed benthic on the leaves of algae or rhizomes, especially in high-energy waters; prefer moderate - warm, shallow, normally marine environments. The combination of a large number of individuals indicates a shallow habitat with high water energy. Planktic forms characteristic of the deep-sea part of the outer shelf (neritic area) ${ }^{24}$.

We give spatial model of ecological distribution of foraminifera in different below (the back-reef, reef and the fore-reef) facias of organogenic constructions $^{25}$. According to the given model (Fig. 8) ${ }^{26}$, it was determined that the association foraminifer of Vanzhuliv village contains elements of the backreef, reef and the fore-reef basins.

Thus, Ammonia, Elphidium (masse), single Ophthalmidium are the main components of the back-reef (lagoon). Representatives of reef facies proper are Miliolida (large forms, more than $1 \mathrm{~mm}$ ), Borelis (mass), single Peneroplis. Indicators of advanced fore-reef facies are the presence in the complex of planktic forms Globorotalia, Anomalinoides ?, Bolivina (single).

23 Szczechura J. Palaeoenvironments of the Middle Miocene evaporite-bearing deposits from the Działoszyce Trough, Carpathian Foredeep, Poland, based on microfaunal studies. Gcol. Quart., 44 (2): Warszawa. 2000. P. 119-135.

Wysocka A., Radwanski A., Gorka M., Babel M., Radwanska U., Zlotnik M. The Middle Miocene of the Fore-Carpathian Basin (Poland, Ukraine and Moldova). Acta Geologica Polonica. Vol. 66. 2016. No. 3. P. 351-401. DOI: 10.1515/agp-2016-0017

${ }^{24}$ BouDagher-Fadel M.K. Evolution and Geological Significance of Larger Benthic Foraminifera. Second edition. UCL Press. London, 2018. $693 \mathrm{p}$. DOI: https://doi.org/10.14324/111.9781911576938

Brânzilă M., Chirilă G., Jitaru M. Micropalaeontologic content of the Sarmatian from Southern Moldavian platform - a Backbulge depozone. Acta Palaeontologica Romaniae. V. 7 (2011). P. 45-59.

${ }^{25}$ BouDagher-Fadel M.K. Evolution and Geological Significance of Larger Benthic Foraminifera. Second edition. UCL Press. London, 2018. 693 p. DOI: https://doi.org/10.14324/111.9781911576938

${ }_{26}$ BouDagher-Fadel M.K. Evolution and Geological Significance of Larger Benthic

Foraminifera. Second edition. UCL Press. London, 2018. 693 p. DOI: https://doi.org/10.14324/111.9781911576938 


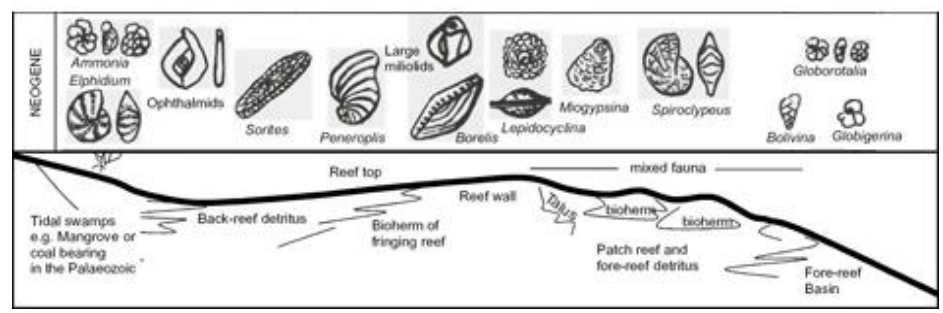

Fig. 8. Spatial model of the structure of organogenic construction (reef, bioherm) and ecological distribution of large and key smaller benthic and planktic foraminifera in the reef basin of the Neogene (Late BadenianSarmatian), compiled according to BouDagher-Fadel M.K., 2018 ${ }^{27}$

The main criteria for determining the facies of reef structures are the systematic composition of fossils and their quantitative ratio in complexes. If Ammonia, Elphidium prevails in the number of associations, will serve as an indicator of back-reef facies. The prevalence in the complexes of Miliolida, Borelis, Peneroplis will be a criterion for the identification of reef facies. In our case, mixed complexes defined from Buhliv beds (Early Sarmatian) Vanzhuliv village is an indicator of the advanced fore-reef basin, which was caused by a number of events in the Middle Miocene - tectono-magmatic activation in the Carpathian folding system, laying and development of the reef construction of Medobory (Late Badenian), its erosion (destruction) at the end of Badenian - the beginning of Sarmatian, which served as the initial material for formation of Sarmatian deposites, in the composition of which complexes of transferred faunas of Late Badenian with elements of appearance of Early Sarmatian forms are found. Thus, in the structure of the fossil association of Buhliv beds there are mixed complexes with elements of different facies and different ages.

Corals (Tab. 3; Fig. 9; A-C).

In the association of microfossils of Buhliv beds fragments of one kind of the reef framework encrusting organisms of the Early-Late Badenian - colonial of hermatypic coral Tarbellastraea reussiana (Milne-Edwards et Haime, 1850) (Tab. 1; Fig. 9; A-C). Within the territory of Poland (the Grobie) it is described from the Early Badenian deposits Gorka ${ }^{28}$. On the territory of Ukraine Tarbellastraea reussiana forms colonies in the area of Maksymivka, Polupanivka, etc. (north-eastern slope of Medobory) (Late Badenian).

${ }^{27}$ BouDagher-Fadel M.K. Evolution and Geological Significance of Larger Benthic Foraminifera. Second edition. UCL Press. London, 2018. 693 p. DOI: https://doi.org/10.14324/111.9781911576938

${ }^{28}$ Gorka M., Studencka B., Jasionowski M., Hara U., Wysocka A., Poberezhskyy A. The Medobory Hills (Ukraine): Middle Miocene Reef Systems in the Parathetys, their biological diversity and lithofacies. Biuletyn Państwowego Instytutu Geologicznego. 2012. № 449. P. 147-174.

Peryt D., Jasionowski M. Sarmatian foraminiferal assemblages of cavern fillings in the Badenian reefs of Medobory (Polupaniwka, Western Ukraine). Biuletyn Państwowego Instytutu Geologicznego. 2012. № 449. P. 175-184. 


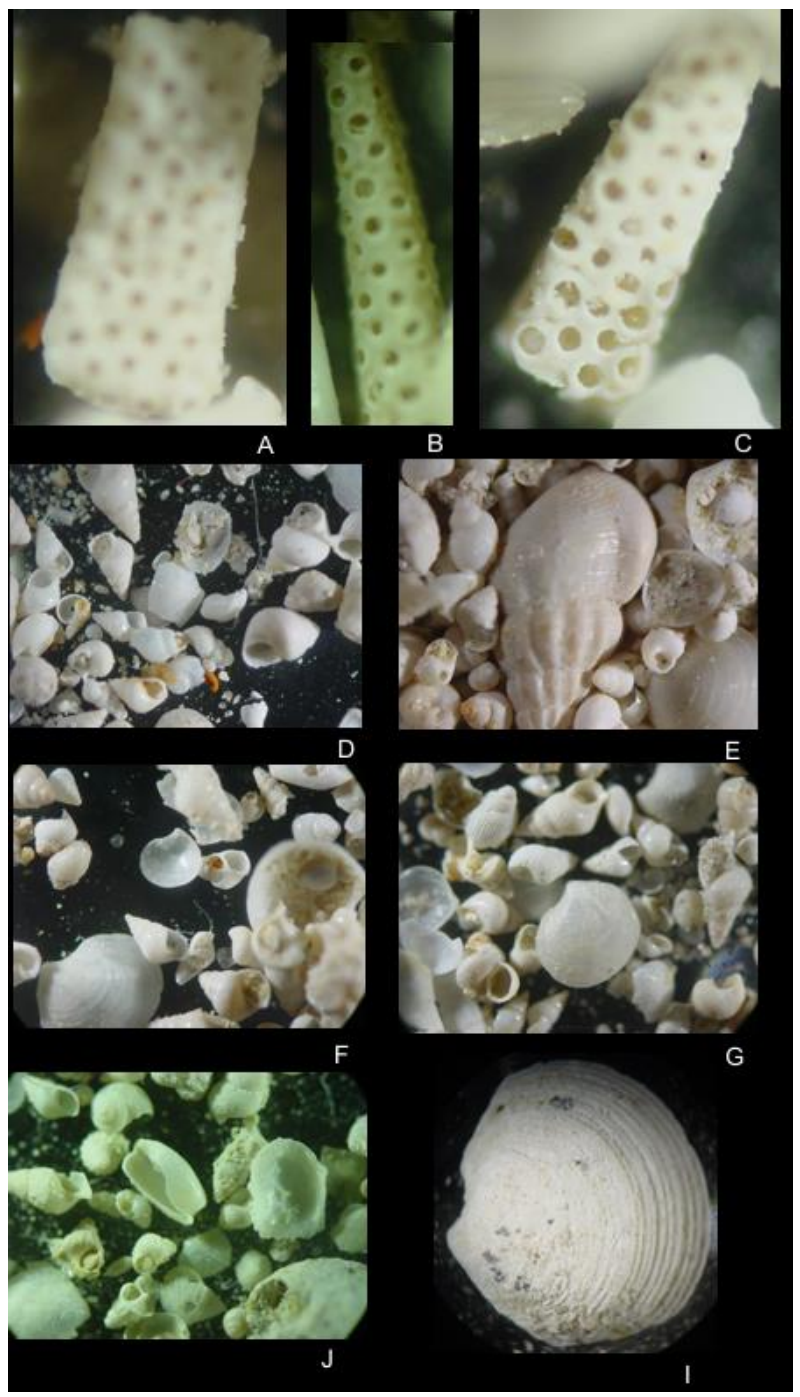

Fig. 9. A-C - fragments skeletons of hermatypic coral Tarbellastraea reussiana (Milne-Edwards et Haime) (encrusting organism of the reef framework); D - skeletons gastropods; E-H - skeletons gastropods and bivalves; I - skeleton bivalve with traces of mechanical and chemical damage 
Molluscs (Tab. 3; Fig. 9; D-I).

Dwarf forms are represented by gastropods (mass), bivalves (in smaller quantity), and scaphopods (single). Systematic structure: gastropods (Turritella, Gastrocopta (Albinula), Gibbula, Theodoxus, Pseudamnicola, Terebralia, Rissoa, Mohrensternia, Alvania (Alvania), Hydrobia, Caspia (Socenia), Duplicata, Ocenebra, Odostomia, Valvata ?, Acteocina, Retusa, Tectura, Granulolabium, Cerithium); bivalves (Vallonia, Anadara, Ostrea (Ostrea), Loripes (Microloripes), Corbula (Varicorbula), Gouldia, Ervillia, Mactra, Cardium, „Chlamys"). In the analysis of molluscks, the main attention was paid to the degree of preservation, substitution, size of skeletons and renewal (first appearance) in complexes. The Badenian forms of milk color, strong, opaque, sculptural, size exceeds $1 \mathrm{~cm}$. The Sarmatian with white, transparent, translucent, fragile skeleton, size up to $1 \mathrm{~cm}$. Smooth non-ornate forms prevail. The exception is Mohrensternia (4 species), Potamides (1 species) from sculptural skeletons of white color. Scaphopoda - Dentaliidae - Antalis quindeciesstriata (Eichwald) are single.

Fragments of Vermetus skeletons are found (Fig. 10; A, B). These marine gastropods have an unusual appearance and life cycle. Very young forms are not different from others as they have a conical, spiral shell. Then they are attached to the solid substrate by means of calcium excretions, and the shell takes the form of a tube folded into tangles of different types. The length of adults is about $30-50 \mathrm{~mm}$, and the cross section of the shell can reach up to $6 \mathrm{~mm}$ in diameter. Small operculum concave. It belongs to sedentary forms of gastropods, the shell of which is attached to a solid substrate or skeletons of other organisms. They are significantly common within reef structures and belong to the encrusting organisms.

Ostracods (Tab. 3; Fig. 10; C, D).

The main distinguishing features are the degree of preservation (replacement of skeletons, thickness of the skeleton - transparent, translucent, opaque) and the ratio of ornamented and smooth-walled taxa. Meet in large quantities. The Badenian forms of limonitized (redish color), phosphatized (brownish color), opaque, thick-walled, predominate sculptured. The Early Sarmatian skeletons are white transparent, translucent, brittle, dominated by thin-walled, and largesize $(1 \mathrm{~mm})$ shapes are found. Systematic structure: the Badenian - Cytherella russoi Sissingh; Paranesidea brevis (Lienenklaus); Triebelina boldi Keij; Eucytherura aff. textilis tridentata Carbonel; Phlyctenophora affinis (Schneider); Parakrithe rotundata (Aielo et al.); Argilloecia acuminata Mueller; Krithe papillosa (Bosquet); Kangarina coarctata Ruggieri; Cytheridea (Cytheridea) acuminata (Bosquet); Pokornyella deformis (Reuss); Tenedocythere sulcatopunctata (Reuss); Aurila (Aurila) opaca (Reuss); Aurila (Aurila) cicatricosa (Reuss); Aurila (Euaurila?) angulata (Reuss); Aurila (Euaurila) punctata (Muenster); Grinioneis haidingeri (Reuss); Henryhowella asperrima (Reuss); Loxocorniculum schmidi (Cernajsek); Loxocorniculum hastatum (Reuss); Loxoconcha kochi Mehes; Loxoconcha punctatella (Reuss); Xestoleberis dispar (Mueller); Xestoleberis tumida (Reuss). The Sarmatian - 
Aurila (Aurila) mehesi (Zalanyi); Cytheridea hungarica Zalányi; Euxinocythere (Euxinocythere) diafana (Stancheva); Callistocythere incostata Pietrzeniuk; Callistocythere postvallata Pietrzeniuk; Amnicythere tenuis (Reuss); Amnicythere sp.; Cytherois sarmatica (Jiřiček); Loxoconcha cf. curiosa Schneider; Loxocorniculum schmidi (Cernajsek); Loxocorniculum hastatum (Reuss); Xestoleberis glabrescens (Reuss).

This group belongs to reef-building organisms of the reef framework, so due to the destruction of biohermic structures, they are also part of the Bugliv beds. Representatives of the Late Badenian and the Early Sarmatian are present. Among Late Badenian found encrusting zoaria of the fan-shaped form of Tubulipora flabellaris (Fabricius), fragments of the branched cheilostome colonies of Steginoporella Smitt.

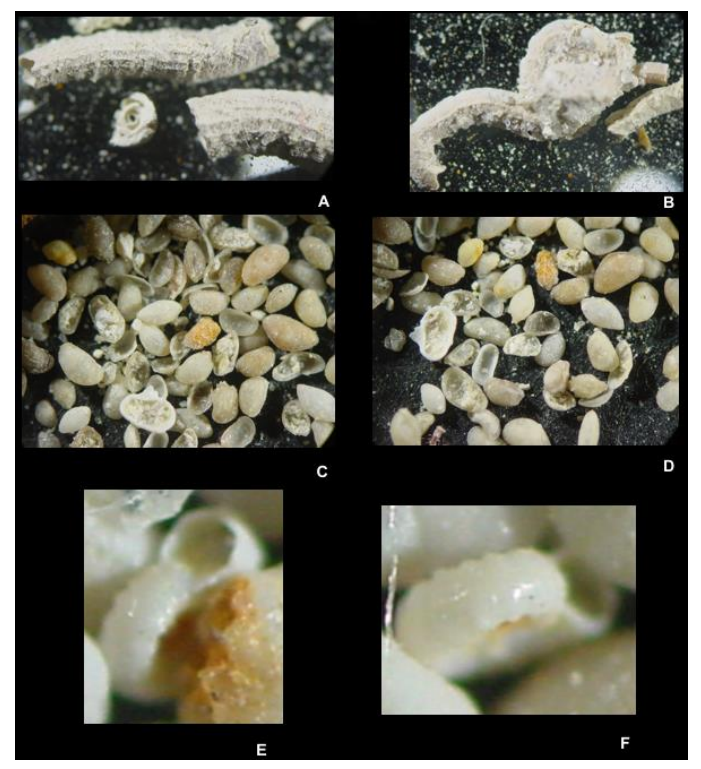

Fig. 10. A, B - fragments skeletons Vermetus; C, D - skeletons ostracods; E, F - skeleton serpulid genus Spirorbis

Bryozoans (Tab. 3; Fig. 11; A-F).

From Early Sarmatian forms found fragments of branched colonies schizoporellids represented by Schizoporella tetragona (Reuss), which in the ecosystem of Medobory, performed the main constructive role. The massiv 
globular zoaria Cryptosula terebrata (Sinzov) are, universal and independent of facies, that forms either encrusting, or branched colonies ${ }^{29}$.

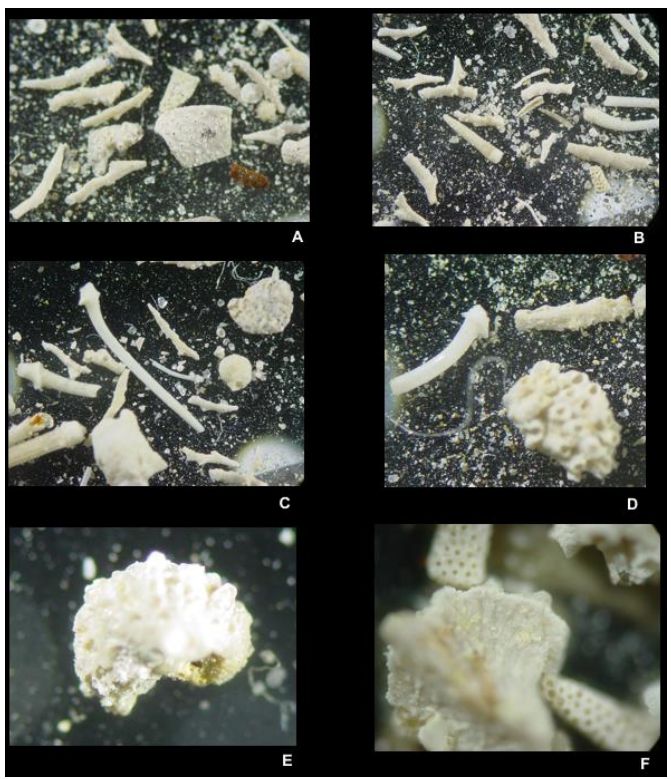

Fig. 11. A - fragments colony of tubuliporinids Cryptosula terebrata (Sinzov) and branching cyclostomid of colonies; B - fragments of associations branched colonies of cyclostomid and needles of Echinodermata; $\mathrm{C}$ - fragments of associations branched colonies of cyclostomid and needles of Echinodermata; D - small colony Celleporina rostrata (Malecki); E, F - encrusting zoarium of Tubulipora flabellaris (Fabricius): $\mathbf{E}$ - view outside; $\mathbf{F}$ - cross section view

${ }^{29}$ Górka M., Studencka B., Jasionowski M., Hara U., Wysocka A., Poberezhskyy A. The Medobory Hills (Ukraine): Middle Miocene Reef Systems in the Parathetys, their biological diversity and lithofacies. Biuletyn Państwowego Instytutu Geologicznego. 2012. № 449. P. 147-174.

Hara U., Jasionowski M. The Early Sarmatian bryozoan Celleporina medoborensis sp. nov. from the Medobory reefs of west ern Ukraine (Central Paratethys). Geological Quarterly. 2012. № 56 (4). P. 895-906.

Vrsaljko D., Pavelić D., Miknić M., Brkic M., Kovacic M., Hećimović I., HajekTadesse V., Avanić R., Kurtanjek N. Middle Miocene (Upper Badenian/Sarmatian) Palaeoecology and Evolution of the Environments in the Area of Medvednica Mt. (North Croatia). Geologia Croatica. Zagreb. 2006. № 59/1. P. 51-63.

Wysocka A., Radwanski A., Gorka M., Babel M., Radwanska U., Zlotnik M. The Middle Miocene of the Fore-Carpathian Basin (Poland, Ukraine and Moldova). Acta Geologica Polonica. Vol. 66. 2016. No. 3. P. 351-401. DOI: 10.1515/agp-2016-0017 
Serpulid (Tab. 3; Fig. 10; E, F).

Members of the genus Spirorbis (Tab. 1; Fig. 10; E, F) are very small (2$5 \mathrm{~mm}$ ) polycheat worms, predominantly with a white spiral skeleton (in our case with a translucent skeleton). Members of the genus live in the lower littoral and sublitoral areas of rocky coasts, and lead a sedentary lifestyle. Spirorbis worms usually live attaching to algae, but some species live directly on rocks, shells, or other solid substrates. Spirorbis limestones is formed in the Early Sarmatian and are represented by single individuals with a translucent skeleton of spiral shape, size $0.5-0.7 \mathrm{~mm}$.

\subsection{Analysis of the degree of preservation of microfossiles}

Table 3

\section{Comparative characteristics of Badenian and Sarmatian forms by degree of skeletons preservation}

\begin{tabular}{|c|c|}
\hline Badenian forms & Sarmatian forms \\
\hline \multicolumn{2}{|c|}{ Foraminifers (Fig. 7) } \\
\hline $\begin{array}{l}\text { Phosphatised (brownish), limonitized } \\
\text { (redish), mechanical damage to the } \\
\text { skeleton (traces of destruction), thick- } \\
\text { walled, fine size taxa. }\end{array}$ & $\begin{array}{l}\text { Skeletons of good safety (without traces of } \\
\text { destruction), white color, transparent, } \\
\text { translucent, the size of some taxa exceeds } 1 \\
\mathrm{~mm} \text {, presence of two generations in species. }\end{array}$ \\
\hline \multicolumn{2}{|c|}{ Corals (Fig. 9) } \\
\hline $\begin{array}{l}\text { Colonies within the reef of Medobory } \\
\text { Hills (Maksymivka, Polupanivka, etc.). }\end{array}$ & $\begin{array}{l}\text { Fragments of colonies (debris, mechanical } \\
\text { damage, yellowish color of individual } \\
\text { remains). }\end{array}$ \\
\hline \multicolumn{2}{|c|}{ Molluscs (Fig. 9, 10) } \\
\hline $\begin{array}{l}\text { Skeletons with erased sculptural elements, } \\
\text { mechanically damaged, thick-walled, with } \\
\text { traces of weak substitution (yellowish, } \\
\text { dairy color), predominate sculptured } \\
\text { shapes, size exceeds } 1 \mathrm{~cm} \text {. }\end{array}$ & $\begin{array}{l}\text { Skeletons of good preservation, white, } \\
\text { transparent, translucent, thin-walled, } \\
\text { predominate smooth-walled shape, size up to } \\
1 \mathrm{~cm} \text {. Renewal of complexes can be traced to } \\
\text { Mohrensteria (4 species), Ervilia, Mactra, } \\
\text { „Chlamys“. }\end{array}$ \\
\hline \multicolumn{2}{|c|}{ Ostracods (Fig. 10) } \\
\hline $\begin{array}{l}\text { Phosphatized (brownish), limonitized } \\
\text { (redish), forms of sculptural, ornamented } \\
\text { skeleton prevail, the wall is thick. }\end{array}$ & $\begin{array}{l}\text { Skeletons of white color, transparent, } \\
\text { translucent, thin-walled, predominate shapes } \\
\text { with smooth-walled skeleton, size of single } \\
\text { taxa exceeds } 1 \mathrm{~mm} \text {. }\end{array}$ \\
\hline \multicolumn{2}{|c|}{ Bryozoans (Fig.11) } \\
\hline $\begin{array}{l}\text { Encrusting zoaria of the fan-shaped form } \\
\text { of Tubulipora flabellaris (Fabricius), } \\
\text { fragments of the branched cheilostome } \\
\text { colonies of Steginoporella } \text { Smitt. }\end{array}$ & $\begin{array}{l}\text { Fragments of branched colonies } \\
\text { schizoporellids represented by Schizoporella } \\
\text { tetragona (Reuss), massiv globular zoaria } \\
\text { Cryptosula terebrata (Sinzov). }\end{array}$ \\
\hline \multicolumn{2}{|c|}{ Serpulid (Fig. 10) } \\
\hline & $\begin{array}{l}\text { Skeletons are spiral-plane, translucent } \\
\text { (Spirorbis), single forms. }\end{array}$ \\
\hline
\end{tabular}




\section{Stratigraphy}

An analysis of the evolution of researchers views regarding the stratigraphic position of Buhliv beds in stratigraphic schemes is considered. In the present stage, the representation of scientists forms two points of view regarding the understanding of the volume and age of these beds (Fig. 12). According to the views of most authors ${ }^{30}$, Buhliv beds cover several lithological beds in volume and date from Early Sarmatian. Behind minority representations ${ }^{31}$, the volume of this stratigraphic unit is reduced to one horizon and its age is defined as the tops of Late Badenian.

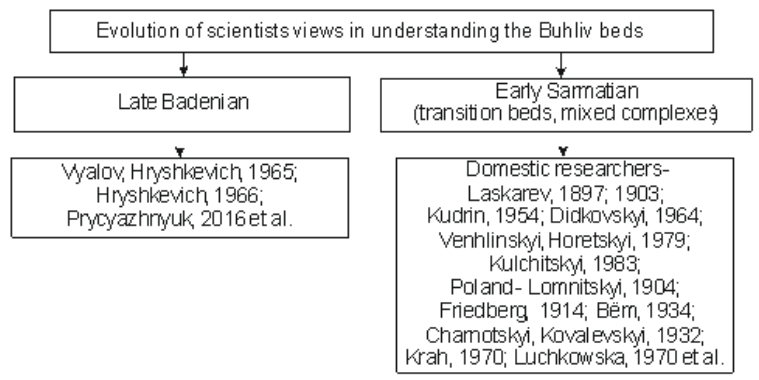

\section{Fig. 12. Researchers positions on understanding the volume, age and stratigraphic position of Buhliv beds over the more than 100-year history of the study}

In stratigraphic schemes (Fig. 13) their position and scope are also debatable and there is no single representation among geologists ${ }^{32}$. In some

30 Бугловские слои миоцена. Материалы Всесоюзного симпозиума. Львов 6-16 сентября 1966 г. Киев : Наук. думка, 1970. 279 с.

Ласкарев В.Д. О сарматских отложениях, некоторых мест Волынской губернии. 3ап. Новорос. о-ва естествоиспьтателей. 1897. № 21. Вып. 2. С. 89-115.

Ласкарев В.Д. Фауна бугловских слоев Волыни. Санкт-Петербург, 1903. 126 с. (Тр. Геол. ком. Нов. сер. Вып. 5).

Бу Булловские слои миоцена: Материалы Всесоюзного симпозиума. Львов 6-16 сентября 1966 г. Киев : Наук. думка, 1970. 279 с.

Присяжнюк В. О переходных слоях рр. Ушицы и Ушки В.Д Ласкарева. Materialete conferintei stiintifice nationale cu participare internationala „Mediul si Dezvoltarea durabila". Editia a III-a consacrata aniversarii a 80 ani de la nasterea prof. univ $_{33}$ dr. hab. Alexandru Lungu. 06-08 octombrie 2016. P. 53-56.

З2 Венглинский И.В., Горецкий В.А. Стратотипы миоценовых отложений Волыно-Подольской плиты, Предкарпатского и Закарпатского прогибов. Киев : Наук. думка, 1979. 176 с.

Королюк И.К. Подольские Толтры и условия их образования. Труды Ин-та геол. наук АН СССР. Сер. геол. 1952. Вып. 110. № 56. 120 с.

Стратиграфічний кодекс України / Відп. ред. П.Ф. Гожик. 2-е вид. Київ, 2012. 66 с.

Vrsaljko D., Pavelić D., Miknić M., Brkic M., Kovacic M., Hećimović I., HajekTadesse V., Avanić R., Kurtanjek N. Middle Miocene (Upper Badenian/Sarmatian) Palaeoecologv and Evolution of the Environments in the Area of Medvednica Mt. (North Croatia). Geologia Croatica. Zagreb. 2006. № 59/1. P. 51-63. 
they meet either the bottom of the Early Sarmatian or the top of the Late Badenian, in others they cover the top of the Late Badenian of the bottom of the Early Sarmatian. Contact with underlying entities is dissenting. The discussion of views is due to the presence of mixed different-age complexes of fossil Badenian and Sarmatian in the Buhliv beds, which led to different understanding of their age.

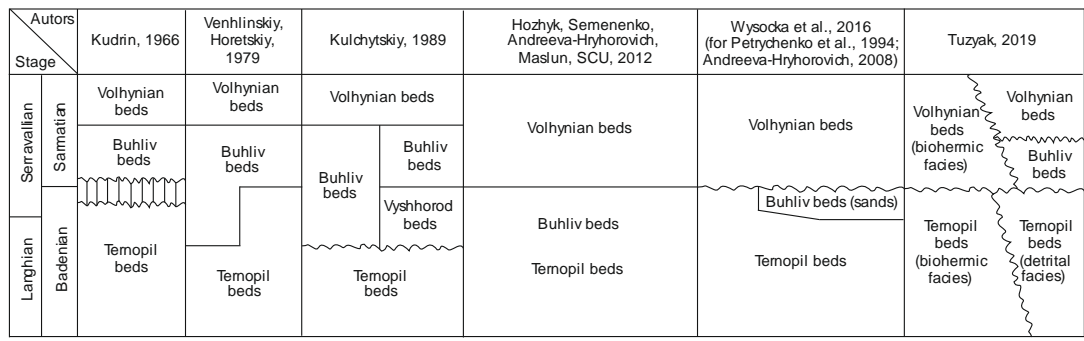

\section{Fig. 13. Evolution of researchers views on the position, volume and age of Buhliv beds in stratigraphic schemes}

In the initial understanding, according to the views of V.D. Laskarev ${ }^{33}$ (Fig. 14), Buhliv beds (BB) are a stratigraphic unit of local rank, first allocated in the territory of the Ternopil region (the former Volhynian Province) in the area of the Buhliv, Ohryshkivtsi, Vanzhuliv villages, etc. These are the transitional beds between Badenian and Sarmatian, which contain a mixed complex of fossils - relict forms of Badenian with the emergence of elements of Sarmatian fauna. In addition, Buhliv beds are a special freshwoter desalinated (saline) fatcie of a part of Late Badenian, combining marine and eurihaline representatives. Stratotype was not listed by the author, but the most complete author considered the incision (natural exposure) with Ohryshkivtsi village. Beds 3 and 4 are separated (Laskarev 7 and 8 according to the description of the components of the section from top to bottom) ${ }^{34}$. It is a sandy layer (at the bottom greenish-grey sands, at the top - white, light-grey sands, total thickness to $7 \mathrm{~m}$ ), carbonate with numerous remains of fossils. We give the layer-by-layer description of a geological section of the Neogene (Miocene) of the right coast of the Buhlivka river, Ohryshkivtsi village (Ternopil region) in which Buhliv beds ( 3 and 4 ) are allocated (Fig. 14) according to V. Laskarev ${ }^{35}$ (from top to bottom).

33 Ласкарев В.Д. Фауна бугловских слоев Волыни. Санкт-Петербург, 1903. 126 с. (Тр. Геол. ком. Нов. сер. Вып. 5).

34 Ласкарев В.Д. Фауна бугловских слоев Волыни. Санкт-Петербург, 1903. 126 с. (Тр. Геол. ком. Нов. сер. Вып. 5).

35 Ласкарев В.Д. Фауна бугловских слоев Волыни. Санкт-Петербург, 1903. 126 с. (Тр. Геол. ком. Нов. сер. Вып. 5). 
According to SCU, $2012^{36}$, the priority rule (protection of their names) applies to the trust departments, which are subject to the rules of the Code. Therefore, the rejection, replacement or modification of the straton and the use of it in practical stratigraphy are decided and accepted by the relevant stratigraphic bodies, in particular the National Stratigraphic Committee of Ukraine. Thus, according to V. D. Laskarev 1897, $1903^{37}$ Buhliv beds in the valleys of the rivers Buhlivka, Svynoryika (the vicinity of the Vyshgorodok, Ohryshkivtsi, Buhliv villages of Ternopil region) were considered in the volume of two components - greenish-grey glauconite sands and white-grey sands. Both varieties contain elements of Badenian and Sarmatian eurihaline fauna. They lie with unconformity on the perfectly flat surface of lithotamnium limestone. Subsequently, with further research, the lower component of the Buhliv beds - a layer of greenish-grained glauconitic sands with rich Badenian marine fauna, V.A. Horetskyi ${ }^{38}$ was isolated into a separate straton - the Vyshgorodok beds and classified as a Late Badenian. Polish (Lomnickyi, 1904; Böm, 1934; Friedberg, 1914; Charnotskyi, Kowalewskyi, 1932; Krah, 1970; Luchkowska, 1970 et al.) and ukrainian (Kulchitskyi, 1983 et al.) researchers.

On the basis of the results of the study of fosills of different systematic composition from this interval, they were considered Early Sarmatian (Goretskyi, 1964; Didkovskyi, 1964; Kudrin, 1954; Venhlinskiyi, 1962; Horetskyi, Didkovskyi, 1975 et al.). However, it should be noted that each of the researchers invested their understanding in the scope of this straton. Also important is the fact that the completeness of the section of the Buhliv beds (its components and thickness) over the area of distribution can change - the lower parts can fall out and the upper parts can be blurred, so it is important to indicate the stratotype (reference section), which most fully reflects the structure and composition (lithological, paleontological) of the subdivision with which its analogues (section fragments) could be compared.

According to the studies of A.S. Vyalov and G.N. Hryshkevich ${ }^{39}$ the volume and stratigraphic positions of the Buhliv beds have been revised and changed. Thus, unlike the original views, according to which the volume of beds before clarification constituted horizons $\mathrm{C}, \mathrm{D}$, according to the decisions of the colloquium were reduced to horizon $\mathrm{D}$ and dated to Late

\footnotetext{
$66 \mathrm{c}$

${ }^{36}$ Стратиграфічний кодекс України / Відп. ред. П.Ф. Гожик. 2-е вид. Київ, 2012.

37 Ласкарев В.Д. Фауна бугловских слоев Волыни. Санкт-Петербург, 1903. 126 с. (Тр. Геол. ком. Нов. сер. Вып. 5).

Ласкарев В.Д. О сарматских отложениях, некоторых мест Волынской губернии. Зап. Новорос. о-ва естествоиспытателей. 1897. № 21. Вып. 2. С. 89-115.

38 Венглинский И.В., Горецкий В.А. Стратотипы миоценовых отложений Волыно-Подольской плиты, Предкарпатского и Закарпатского прогибов. Киев : Наук. думка, 1979. 176 с.

Бугловские слои миоцена: Материалы Всесоюзного симпозиума. Львов 6-16 сентября 1966 г. Киев : Наук. думка, 1970. 279 с.
} 
Tortonian (Badenian). The same view is held by V. Prysyazhnyuk. On the basis of the study of continental molluscs from the transitional beds Ushitsa, Ushky and Kalyus, the author ${ }^{40}$ believes that they, like the Buhliv beds of the D Ohryshkivtsi horizon of Volhyn, are brackish water facies of the Vyshgorodok beds of Badenian.

\section{Buhliv beds (BB)}

1. Dense grey-brownish limestone with obscure Badenian remains, visible thickness more than $1.5 \mathrm{~m}$.

2. Lithotamnium limestone with properly formulated and weakly bound often recrystallized beads; in the middle there is a layer of more loose limesandstone rock, thanks to which the upper part of limestone acts as a cornice; with the exception of minor Ostrea and Pecten elegans Andrz., no other remains have been found. The thickness is more than $4 \mathrm{~m}$.

3. Greenish-gray fine-grained sand. In its upper parts there are sometimes small Ervilia podolica i E. trigonula, in the lower horizons there are thin layers of larger grained with pebbles, yellow sand containing finely ground shell detritus; down these layers increase, become significant and among the debris of the sinks it is possible to distinguish the sea forms belonging to Ostrea, Lucina columbella Lam., Trochus patulus Brocc. The thickness is more than $4 \mathrm{~m}$.

Green-grey sand lies on the flat surface of the underlying layer of organogenic rock.

4. White-grey fine-grained sand, in it miriads of small Ervilia podolica var. dissita Eichwald, Ervilia trigonula Sokol., Mactra fragilis var. buglovensis Lask., Modiola volhynica Eichwald, Cardium lithopodolicum Dub. var. ruthenica Hilb., Cardium sp., Syndesmya scythica Sokol., S. reflexa Eichwald, Donax dentiger Eichwald, Lucina dentate Bast., Venus konkensis var. media Sokol., Venus umbonaria Lam. var., Corbula gibba Ol., Congeria sandbergeri Andrus., typ. et var. buglovensis, Buccinum aff. coloratum Eichwald var. sarmatica Lask., Buccinum duplicatum verneuili Sinz., Mohrensternia inflata Andrus., Bulla lajonkaireana Bast. The thickness to $2,5 \mathrm{~m}$.

5. Dirty-brown serpulid-microbialite sand limestone with Ervilia podolica Eichwald, Cardium protractum Eichwald, Mactra fragilis Lask., Modiola volhynica Eichwald, Serpula sp. The thickness is more than $2 \mathrm{~m}$.

6. White sand with numerous modifications Modiola volhynica Eichwald, Ervilia podolica Eichwald, Cardium protractum Eichwald, C. vindobonense Partsch., Buccinum dublicatum Sow., Cerithium mitrale Eichwald et var. nympha, Hydrobia frauenfeldii Hörn. In it there are thin layers and a cluster of broken and erased shells of Badenian forms Ostrea

${ }^{40}$ Присяжнюк В. О переходных слоях рр. Ушицы и Ушки В.Д Ласкарева. Materialete conferintei stiintifice nationale cu participare internationala „Mediul si Dezvoltarea durabila". Editia a III-a consacrata aniversarii a 80 ani de la nasterea prof. univ., dr. hab. Alexandru Lungu. 06-08 octombrie 2016. P. 53-56. 
digitalina Eichwald, Cardium pracechinatum Hilb., Trochus patulus Brocc. The thickness to $1 \mathrm{~m}$.

7. Interlayer dirty greenish, fatty, brown-spotted clays with layers of light grey-white marl and limestone nodules; among the clays, the lens layers of sand are traced. At the bottom of this group there is a thickness layer (up to $50 \mathrm{~cm}$ ) of white fine-layered marl, the layers of which are divided by brown or coal black carts, on the surfaces of marl lamination there are numerous moulds and shells Cardium protractum Eichwald, C. vindobonense Partsch., Tapes gregaria Pt., Modiola volhynica Eichwald, as well as obscure traces of plants. The thickness is more than $5 \mathrm{~m}$.

8. Finely layered yellowish-grey, sometimes wet, sands with plate-like nodules of lime, more than $1 \mathrm{~m}$.

9. Yellow-brownish loam with numerous limestone braces, more than $2 \mathrm{~m}$. In the bottom is considerably sandstone.

10. Soil-plant layer, up to $1 \mathrm{~m}$.

Thus, according to the decisions of the 1970 colloquium, Buhliv beds (Fig. 15) should be considered only horizon (bed) D, beds with Venus konkensis var. media ( $V$. sobieskii var. media) or the microfaunistic horizon (zone) Streblus (Ammonia) galicianus (Putrja).

By age Buhliv beds (horizon D) belongs to Late Badenian (Tortonian), and actually to Sarmatian must belong to beds that contain typical Sarmatian fauna without traces of relict fossil Badenisn.

According to the biostratigraphic schemes of the Neogen ${ }^{41}$, in particular for the Transcarpathian foredeep, the Preblacksean species Venus konkensis var. media (V. sobieskii var. media) characterizes Late Badenian formations and within Podillya it is found in Ternopil beds.However, G.N. Hryskevich and the co-authors did not consider the possibility of re-placing macrofossils, which could be due to erosion regressive facies of sediments accumulation (erosion), the starting material for which was also deposits of Late Badenian.The accumulation of a bed of $E_{1}$ (Sarmatian age) is associated with a new Sarmatian transgression (sea migration from the north-west to the south-east).

The author's presentation on the Buhliv beds based on previous studies of the section with Vanzhuliv village (Ternopil region):

1) Mixed complexes are found by us in the basis of organogenically detritus layer with mass detection of macrofaunistic remines of members ofBadenian molluscs Gastropoda, Bivalvia, Scaphopoda. In organogenically detrital layer $(0.5-0.6 \mathrm{~m})$ there is a gradation from the bottom up: $20 \mathrm{~cm}-$ accumulation of shells Glycymeris; $20 \mathrm{~cm}$ - organogenic detritus from different members of molluscs shells; $20 \mathrm{~cm}$ - is a skeletons of Trochus sinks with a preserved inner pearlescent layer.

41 Венглинский И.В., Горецкий В.А. Стратотипы миоценовых отложений Волыно-Подольской плиты, Предкарпатского и Закарпатского прогибов. Киев : Наук. думка, 1979. 176 с. 


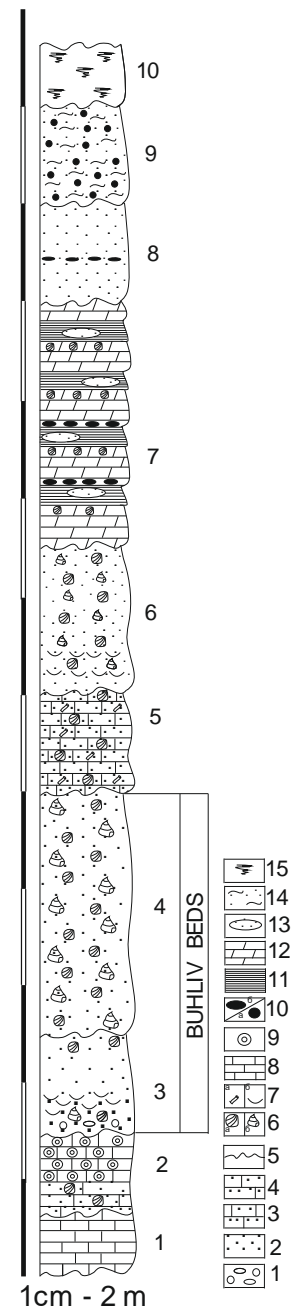

Fig. 14. Understanding the position, geological age and volume of the Buhliv beds V. D. Laskarev's ${ }^{42}$

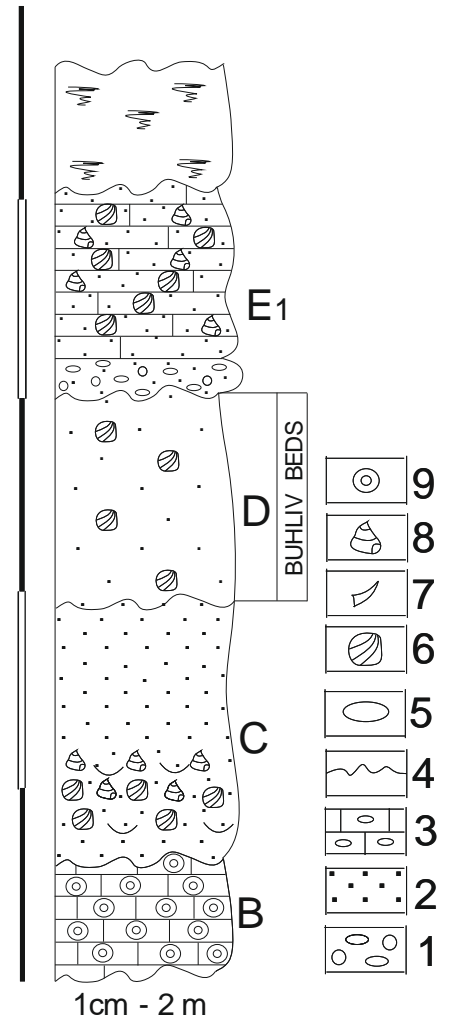

Fig. 15. Understanding the position, volume and age of the Buhliv beds behind Vyalov and Hryshkevich

Legend: 1 - pebbles, gravel; 2 - sands; 3 - sandstone limestone; 4 - limestone sandstones; 5 - unconformity; 6 - molluscs: bivalve $(a)$, gastropods $(b) ; 7$ - serpulids $(a)$, scaphopods $(b) ; 8$ - limestones;

9 - litotamnium; 10 - carbonate nodules $(a)$, braccies $(b) ; 11$ - clays; 12 - marl; 13 - sand lenses; 14 - loess loam; 15 - soil-plant layer

42 Ласкарев В.Д. Фауна бугловских слоев Волыни. Санкт-Петербург, 1903. 126 с. (Тр. Геол. ком. Нов. сер. Вып. 5). 
2) Microfaunistic complexes have been detected and studied from the moulds of the Glycymeris sinks, characterized by good safety and the presence of two flaps. The moulds are represented by light grey to white weakly cemented finegrained sandstones. Here the remains of microfossils Foraminifera, Ostracoda, Gastropoda, Bivalvia, Scaphopoda, Bryozoa, Serpula, fragments of corals, needles of sea urchins have been found. As a result of the microfaunistic analysis, the mixed character of the complexes was found in fossil groups such as foraminifers, molluscs (gastropods, bivalves), ostracods, bryozoans, among them important biostratigraphic importance for Sarmatian are: Foraminifera: Anomalinoides dividens (Luchkowska, 1967) (Fig. 7; E, F), Globorotalia menardii (d'Orbigny in Parker, Jones et Brady, 1865) (Fig. 15), Elphidium reginum (d'Orbigny), E. hauerinum (d'Orbigny), Porosononion granosum (d'Orbigny) et al.); Mollusca: Mohrensternia, Ervilia, Mactra - Ervilia dissita (Eichwald), Ervilia trigonula Sokolov, Sarmatimactra vitaliana (d'Orbigny), S. eichwaldi (Laskarev), Venerupis gregarius ponderosus (d'Orbigny), V. gregarius gregarius (Goldfuss), Mohrensternia banatica Jekelius, Granulolabium bicinctum (Brocchi), Hydrobia frauenfeldi (Hoernes), Agapilia picta (Ferussac), Cerithium rubiginosum Eichwald, Duplicata duplicata (Sowerby), Potamides disjunctus (Sowerby), Gibbula buchi (Dubois), Mitrella agenta Harzhauser et Kowalke; Ostracoda: Cytheridea hungarica (Zalányi), Aurila mehesi (Zalányi), Aurila merita (Zalányi), Loxoconcha schmidi Cernajsek, Hemicytheria omphalodes omphalodes (Reuss), Callistocythere sp., Xestoleberis glaberescens (Reuss), for which zones are allocated in a number of regions belonging to Central Paratethys ${ }^{43}$ and Podillya (Western Ukraine) (Fig. 16).

${ }^{43}$ Bolli H.M., Saunders J.B. Oligocene to Holocene low latitude planktic foraminifera. Bolli H.M., Saunders J.B., Perch-Nielsen K. (Eds.). Plankton Stratigraphy. Cambridge University Press, Cambridge, 1985. P. 155-262.

Boudagher-Fadel M. Biostratigraphical and geological significance of planktonic foraminifera. Updated second edition. UCLPRESS. University College London, 2015. 298 p. DOI: 10.14324/111.9781910634257

Brânzilă M., Chirilă G., Jitaru M. Micropalaeontologic content of the Sarmatian from Southern Moldavian platform - a Backbulge depozone // Acta Palaeontologica Romaniae. V. 7 (2011). P. 45-59.

Filipescu S., Silye L. New Paratethyan biozones of planktonic foraminifera described from the Middle Miocene of the Transylvanian Basin (Romania). Geologica Carpathica, December 2008. 59. 6. P. 537-544.

Fordinal K., Zágoršek K., Zlinská A. Early Sarmatian biota in the northern part of the Danube Basin (Slovakia). Geologica Carpathica, April 2006. 57. 2. P. 123-130.

Gebhardt H., Zorn I., Roetzel R. The initial phase of the early Sarmatian (Middle Miocene) transgression. Foraminiferal and ostracod assemblages from an incised valley fill in the Molasse Basin of Lower Austria. Austrian Journal of Earth Sciences. 2009. Vol. 102/2. P. 100-119.

Harzhauser M., Piller W.E. Integrated stratigraphy of the Sarmatian (Upper Middle Miocene) in the western Central Paratethys. Stratigraphy. 2004. № 1(1). P. 65-86.

Palcu D.V., Tulbure M., Bartol M., Kouwenhoven T.J., Krijgsman W. The Badenian-

Sarmatian Extinction Event in the Carpathian foredeep basin of Romania: paleogeographic changes in the Paratethys domain. Global and Planetary Change. 2015. 36 p. DOI: 10.1016/j.gloplacha.2015.08.01

Peryt D., Jasionowski M. Sarmatian foraminiferal assemblages of cavern fillings in the Badenian reefs of Medobory (Polupaniwka, Western Ukraine). Biuletyn Państwowego Instytutu Geologicznego. 2012. № 449. 175-184. 


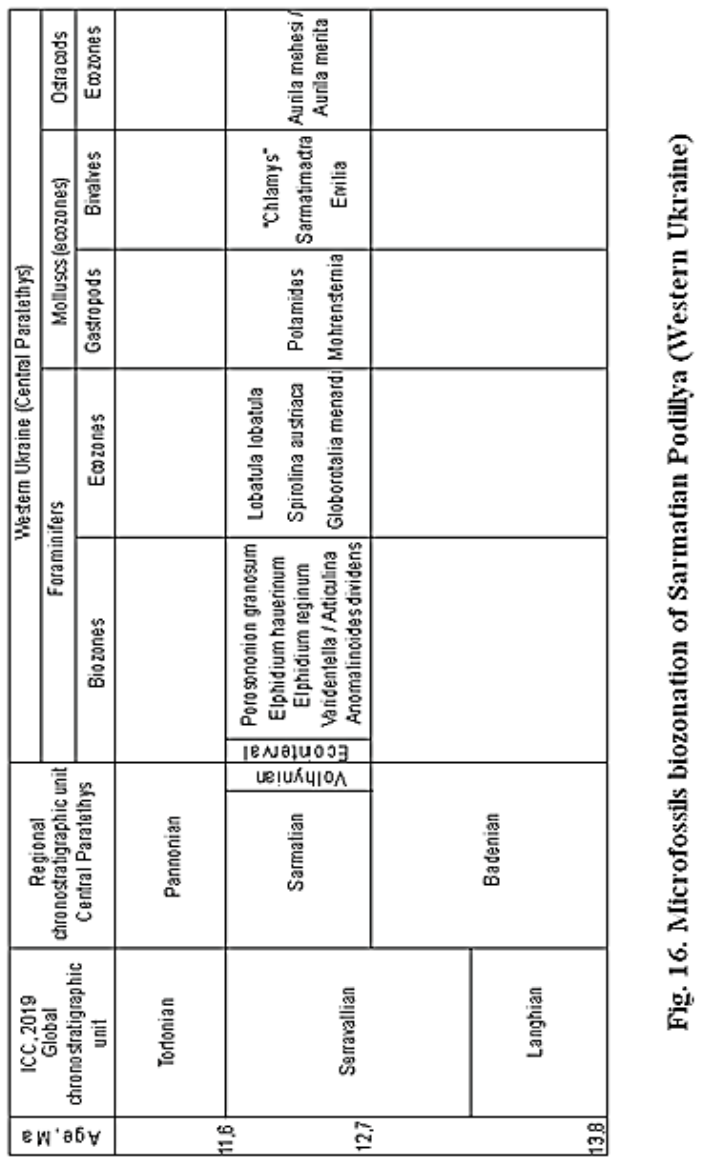

In the Mediterranean, Caribbean, Indo-Pacific regions, the planktic foraminifer form of the Globorotalia menardi has a wide distribution and belongs to the species cosmopolitan. Fig. 17 shows its position in the Late

Piller W.E, Harzhauser M. The myth of the brackish Sarmatian Sea. Terra Nova. 2005. № 17. P. 450-455. DOI: 10.1111/j.1365-3121.2005.00632.x

Piller W.E, Harzhauser M. The myth of the brackish Sarmatian Sea. Terra Nova. 2005. № 17. P. 450-455. DOI: 10.1111/j.1365-3121.2005.00632.x

Selmeczi I., Lantos M., Bohn-Havas M., Nagymarosy A., Szegö E. Correlation of bioand magnetostratigraphy of Badenian sequences from western and northern Hungarv. Geologica Carpathica. 2012. № 63(3). P. 219-232. DOI: https://doi.org/10.2478/v10096012-0019-1

Wysocka A., Radwanski A., Gorka M., Babel M., Radwanska U., Zlotnik M. The Middle Miocene of the Fore-Carpathian Basin (Poland, Ukraine and Moldova). Acta Geologica Polonica. 2016. Vol. 66. No. 3. P. 351-401. DOI: 10.1515/agp-2016-0017 
biostratigraphic schemes of Europe, Central America and the Indo-Pacific. The cosmopolitanism of the taxon makes it possible to compare sections of remote territories. For the first time, representatives of Globorotalia menardi appear in Badenian and continue their existence in Sarmatian. Analysis of the material of the Buhliv beds contributed to the identification of the difference in the morphology of skeletons between forms of Badenian and Sarmatian.

\begin{tabular}{|c|c|c|c|c|c|c|}
\hline \multicolumn{2}{|c|}{ Stage } & Meditterranear & Meditterranean & $\begin{array}{c}\text { Trinidad } \\
\text { Caribbean Sea }\end{array}$ & Indo-Pacific & $\begin{array}{c}\text { Meditterranean } \\
\text { Indo-Pacific }\end{array}$ \\
\hline \multicolumn{2}{|c|}{ Autors } & Bizon, 1972 & $\begin{array}{c}\text { laccarino S., } \\
\text { Salvatorini G., } 198 \\
\text { laccarino S., } 1985\end{array}$ & $\begin{array}{c}\text { Bolli H.M, } \\
\text { Saunders J.B. } \\
1985\end{array}$ & $\begin{array}{c}\text { Kennett J.P., } \\
\text { Keller G., } \\
\text { Srinivasan., } 1985\end{array}$ & \begin{tabular}{|c|} 
Boudagher- \\
Fadel M., \\
2015
\end{tabular} \\
\hline 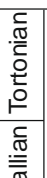 & \multirow[t]{2}{*}{ 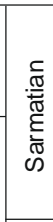 } & $\begin{array}{c}\text { Globorotalia } \\
\text { menardi }\end{array}$ & \multirow[t]{3}{*}{$\begin{array}{c}\text { Globorotalia } \\
\text { menardi }\end{array}$} & \multirow[t]{3}{*}{$\begin{array}{l}\text { Globorotalia } \\
\text { menardi }\end{array}$} & \multirow[t]{3}{*}{$\begin{array}{l}\text { Globorotalia } \\
\text { menardi }\end{array}$} & \multirow[t]{3}{*}{$\begin{array}{l}\text { Globorotalia } \\
\text { menardi }\end{array}$} \\
\hline 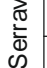 & & & & & & \\
\hline 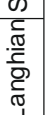 & 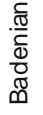 & & & & & \\
\hline
\end{tabular}

\section{Fig. 17. Position of the Globorotalia menardi biostratigraphic zone in the Mediterranean, Atlantic and Pacific Ocean schemes ${ }^{44}$}

Thus, Badenian taxa are characterized by the presence of a keel, a smaller number of chambers in the last turn (6-7), and a small size of remains, while Sarmatian non-keels, with a larger number of cameras in the last turn (8-9) and larger sizes. Another feature of the different ages of this species is the degree of preservation of the skeleton - Badenian is characterized by a strong and thick skeleton (opaque, a wall of yellowish color); Sarmatian have a thin, fragile, white, translucent skeleton. Such changes in structure may indicate a change in salinity of the margin basin at the Badenian/Sarmatian boundary.

The analysis of microfossils from the Buhliv beds (Fig. 18) and the definition of criteria for their identification enabled the author to confirm

${ }^{44}$ Bolli H.M., Saunders J.B. Oligocene to Holocene low latitude planktic foraminifera. Bolli H.M., Saunders J.B., Perch-Nielsen K. (Eds.). Plankton Stratigraphy. Cambridge University Press, Cambridge, 1985. P. 155-262.

Boudagher-Fadel M. Biostratigraphical and geological significance of planktonic foraminifera. Updated second edition. UCLPRESS. University College London, 2015. 298 p. DOI: $10.14324 / 111.9781910634257$ 
V.D. Laskarev's position ${ }^{45}$ regarding the presentation, understanding, scope and stratigraphic position of the straton and to supplement their characteristic.

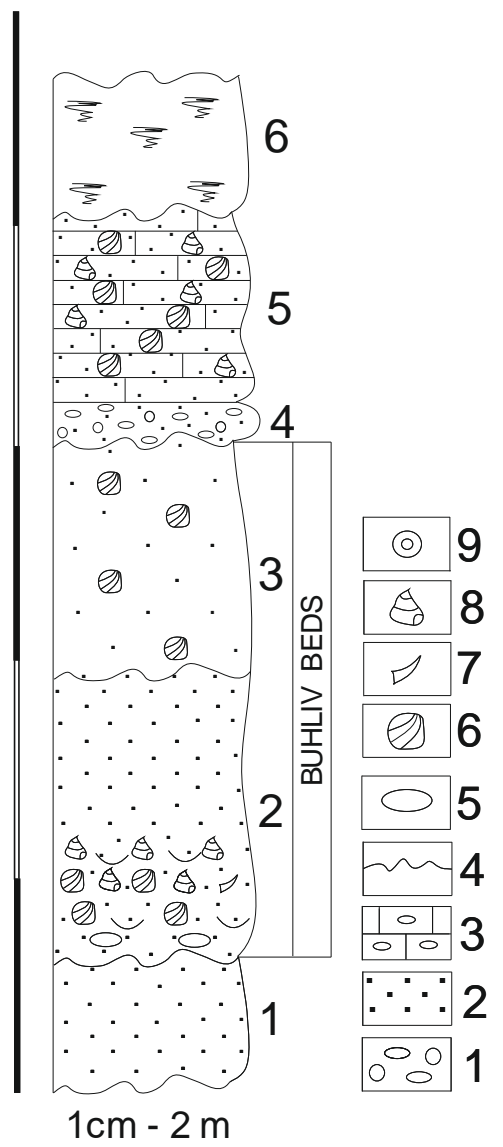

Fig. 18. Stratigraphic position, age and volume of Bugliv beds according to author's research

Legend: 1 - pebbles, gravel; 2 - sands; 3 - sandstone limestone; 4 - limestone sandstones; 5 - unconformity; 6 - molluscs: bivalve $(a)$, gastropods $(b)$; 7 - serpulids $(a)$, scaphopods $(b)$;

8 - limestones; 9 - litotamnium; 10 - carbonate nodules $(a)$, braccies $(b)$; 11 - clays; 12 - marl; 13 - sand lenses; 14 - loess loam; 15 - soil-plant layer

Found associations of microfauna of Buhliv beds have distinct stratigraphical, biostratigraphical, facial and paleoecological criteria.

The stratigraphic criterion - with the uncocphormity of erosion regressive type of Buhliv beds lie on the underlying different age stratons of Badenian and are blocked with a hiatus by the junior formations of Sarmatian; these transition beds between Badenian and Sarmatian, contain a

45 Ласкарев В.Д. Фауна бугловских слоев Волыни. Санкт-Петербург, 1903. 126 с. (Тр. Геол. ком. Нов. сер. Вып. 5). 
mixed different-age complex of microfossils (relict forms of Badenian with the appearance of elements of Sarmatian microfauna).

According to the CGU, $2012^{46}$, this stratigraphic unit by biostratigraphic criteria can be regarded as an ecointerval, because it is characterized by a number of co-ecosone (found in all studied systematic groups) that contact in section (ecoson is a collection of rocks that contains organic remains that reflect a certain life-long ecological association of ancient organisms or taphocenomical features. Co-ecozones that contact in section can be combined into eco-intervals).

Facial criterion - contain the mixed complex of minerals of various facial accessory - fore-reefal, reefal and back-reefal facias of organogenic constructions. Mixed complexes are characteristic of fore-reefal facies. Were created owing to destruction of reefal structure of the main Medobory belt.

Paleoecological criterion - Buhliv beds are a special brackish-water (mixo-mesohaline) environment part of Late Badenian/Early Sarmatian combining marine and eurihaline taxa.

\subsection{Badenian/Sarmatian boundary in regional aspect}

The event, which appeared at the boundary of Badenian/Sarmatian in the regions belonging to Central Paratethys, is synchronous and has clear regional signs, but estimates of its age are diachronous in time. They range within $12.7 \mathrm{Ma}$ based on correlations with global low standing ${ }^{47}$ (Harzhauser \& Piller, 2004; Piller et al., 2007; Paulissen et al., 2011) up to $13.32 \mathrm{Ma}$ compared to astronomical dating ${ }^{48}$ (Lirer et al., 2009). Most of these age models are based on geological data from the study of shallow water, margin subbasins in the western regions of Central Paratethys, where the BSEE level is marked erosion regressive type of boundary in the sedimentary cover.

Important in defining and dating the Badenian/Sarmatian boundary was to find appropriate levels of correlation between successive cycles (eustatic levels) of sea standing, magneto- and biostratigraphy, and volcanic cycles of

\footnotetext{
${ }^{46}$ Стратиграфічний кодекс України / Відп. ред. П.Ф. Гожик. 2-е вид. Київ, 2012. 66 с.

${ }^{47}$ Harzhauser M., Piller W.E. Integrated stratigraphy of the Sarmatian (Upper Middle Miocene) in the western Central Paratethys. Stratigraphy. 2004. № 1(1). 65-86.

Palcu D.V., Tulbure M., Bartol M., Kouwenhoven T.J., Krijgsman W. The BadenianSarmatian Extinction Event in the Carpathian foredeep basin of Romania: paleogeographic changes in the Paratethys domain. Global and Planetary Change. 2015. 36 p. DOI: 10.1016/j.gloplacha.2015.08.01

Paulissen W., Luthi S., Grunert P., Coric S., Harzhauser M. Integrated high-resolution stratigraphy of a Middle to Late Miocene sedimentary sequence in the central part of the Vienna Basin. Geologica Carpathica. 2011. № 62(2). P. 155-169. DOI: 10.2478/v10096011-0013-Z

${ }^{48}$ Lirer F. et al. Astronomically forced teleconnection between Paratethyan and Mediterranean sediments during the Middle and Late Miocene. Palaeogeography, Palaeoclimatology, Palaeoecology. 2009. № 275(1-4). P. $1-13$. DOI10.1016/j.palaeo.2009.01.006
} 
the Alpine orogenic folding stage. Thus, the largest parte (maximum transgression) of Late Badenian can be correlated with the third cycle of sea level (TB 2.5 after Haq et al., 1988), calibrated according to the new time frame, using magnetostratigraphic markers, as a synchronous event for the Sarmatian base of about 12.7-12.8 Ma, which was followed by other authors $^{49}$. Thus, the Badenian/Sarmatian boundary was placed within 12.829 Ma, which are the top of polarity Chron C5Ar.2n (Ogg, 2012). Other authors supported these dating (Piller et al. 2007; De Leeuw et al. 2012, 2013) because they compared well with Mi4 (Turco et al., 2001), which coincides with the lowest sea standing level C3 the Atlantic (Kominz et al. 2008) and brings the Badenian/Sarmatian boundary closer to the Ser 3 sequence boundary (Hardenbol et al., 1998) and is about $12.7 \mathrm{Ma}$ (Tab, 4; Fig. 2) ${ }^{50}$.

Table 4

Badenian/Sarmatian boundary model in Central Paratethys ${ }^{51}$

\begin{tabular}{|c|c|c|c|c|}
\hline $\mathrm{Nr}$ & Age, Ma & Author & Method & Limitations \\
\hline 1. & 12.829 & $\begin{array}{l}\text { Hohenegger, } \\
2014\end{array}$ & $\begin{array}{l}\text { Correlations between third sea-level } \\
\text { cycle (TB } 2.5 \text { after Haq et al. 1988) and } \\
\text { magnetostratigraphy to the top of } \\
\text { polarity Chron C5Ar.2n (Ogg 2012). }\end{array}$ & $\begin{array}{l}\text { Hiatus in the record } \\
\text { at the BSEE level. }\end{array}$ \\
\hline 2. & 12.80 & $\begin{array}{l}\text { De Leeuw et } \\
\text { al., } 2013\end{array}$ & $\begin{array}{l}\text { Bio-Magneto-Stratigraphy in the } \\
\text { Transylvanian Basin }\end{array}$ & $\begin{array}{c}\text { Hiatus in the data at } \\
\text { the BSEE level - } \\
\text { low resolution }\end{array}$ \\
\hline 3 & 13.15 & $\begin{array}{l}\text { Selmeczi et } \\
\text { al., } 2012\end{array}$ & Bio-Magneto-Stratigraphy on drill cores & $\begin{array}{l}\text { Hiatus in the record } \\
\text { at the BSEE level. }\end{array}$ \\
\hline 4. & $\begin{array}{c}12.735- \\
12.474\end{array}$ & $\begin{array}{l}\text { Paulissen et } \\
\text { al., } 2011\end{array}$ & $\begin{array}{l}\text { Correlations of the BSEE with the } \\
\text { C5Ar.1r. }\end{array}$ & $\begin{array}{l}\text { Hiatuses and } \\
\text { difficulties in } \\
\text { correlations at the } \\
\text { BSEE levels. }\end{array}$ \\
\hline 5. & 13.32 & $\begin{array}{l}\text { Lirer et al., } \\
\quad 2009\end{array}$ & $\begin{array}{c}\text { Astronomical dating by correlation } \\
\text { between an orbital tuned Middle and } \\
\text { early Late Miocene record of the Central } \\
\text { Paratethys and an astronomically } \\
\text { calibrated Mediterranean deep marine } \\
\text { composite record. }\end{array}$ & $\begin{array}{l}\text { Not excluded that } \\
\text { the well-data was } \\
\text { obscured by a hiatus } \\
\text { at that crucial level. }\end{array}$ \\
\hline 6. & $<13.13$ & $\begin{array}{l}\text { Śliwiński, } \\
2015\end{array}$ & $\begin{array}{l}\text { Radiometric dating of ash levels older } \\
\text { than the BSEE. }\end{array}$ & $\begin{array}{c}\text { Insufficient } \\
\text { constraints to } \\
\text { provide an age. }\end{array}$ \\
\hline 7. & 12.73 & $\begin{array}{l}\text { Hohenegger, } \\
2009\end{array}$ & $\begin{array}{c}\text { Correlation with the recalculated } \\
\text { Thirdorder sequence TB2.6 of Haq et al } \\
\text { (1988). }\end{array}$ & $\begin{array}{l}\text { Hiatus in the record } \\
\text { at the BSEE level. }\end{array}$ \\
\hline
\end{tabular}

${ }^{49}$ Hohenegger J., Ćorić S., Wagreich M. Timing of the Middle Miocene Badenian Stage of the Central Paratethys. Geologica Carpathica. February 2014. № 65. 1. P. 55-66. DOI: 10.2478/geoca-2014-0004

50 Palcu D.V., Tulbure M., Bartol M., Kouwenhoven T.J., Krijgsman W. The Badenian-Sarmatian Extinction Event in the Carpathian foredeep basin of Romania: paleogeographic changes in the Paratethys domain. Global and Planetary Change. 2015. 36 p. DOI: $10.1016 /$ j.gloplacha.2015.08.01 
Continuation of Table 4

\begin{tabular}{|c|c|c|c|c|}
\hline Nr & Age, Ma & Author & Method & Limitations \\
\hline 8. & 12.72 & $\begin{array}{c}\text { Piller et al., } \\
2007\end{array}$ & $\begin{array}{c}\text { Correlations with sea level low stands } \\
\text { such as the glacio-eustatic isotope } \\
\text { event MSi-3 (Abreu \& Haddad 1998). }\end{array}$ & $\begin{array}{c}\text { Hiatus in the record } \\
\text { at the BSEE level. }\end{array}$ \\
\hline 9. & 13.00 & $\begin{array}{c}\text { Westerhold } \\
\text { et al., 2005 } \\
10 .\end{array}$ & $\begin{array}{c}\text { Correlations with the benthic } \\
\text { foraminiferal } \delta 18 \text { O to the Mi4 event - } \\
\text { one of the short periods of glaciation } \\
\text { in the Miocene (Mievents) described } \\
\text { by Miller et al. (1991). }\end{array}$ & $\begin{array}{c}\text { Hiatus in the record } \\
\text { at the BSEE level. }\end{array}$ \\
\hline $12,86 \pm 0,7-$ & $\begin{array}{c}\text { Pryhodko, } \\
\text { Ponomaryov } \\
\text { a, 2018 }\end{array}$ & $\begin{array}{c}\text { Correlation with volcanic cycles } \\
\text { (radiometric dating) of the orogenic } \\
\text { stage in the Carpathian folding system } \\
\text { (Transcarpathian foredeep). }\end{array}$ & $\begin{array}{c}\text { Hiatus in the record } \\
\text { at the BSEE level. }\end{array}$ \\
\hline $12,77 \pm 0,63$ & Tuzyak, 2019 & $\begin{array}{c}\text { Biostratigraphic criteria in Podillya } \\
\text { (bentonite bed, first appearance of } \\
\text { Anomalinoides dividens, two } \\
\text { generation of planktic forms of } \\
\text { Globorotalia menardii). }\end{array}$ & $\begin{array}{c}\text { Hiatus in the record } \\
\text { at the BSEE level. }\end{array}$ \\
\hline
\end{tabular}

51 Hohenegger J., Ćorić S., Wagreich M. Timing of the Middle Miocene Badenian Stage of the Central Paratethys. Geologica Carpathica. February 2014. № 65. 1. P. 55-66. DOI: $10.2478 /$ geoca-2014-0004

De Leeuw A., Filipescu S., Matenco L., Krijgsman W., Kuiper K., Stoica M. Paleomagnetic and chronostratigraphic constraints on the middle to late Miocene evolution of the Transylvanian basin (Romania): Implications for central Paratethys stratigraphy and emplacement of the Tisza-Dacia plate. Global and Planetary Change. 2013. № 103(1). P. 82-98. DOI:10.1016/j.gloplacha.2012.04.008

Selmeczi I., Lantos M., Bohn-Havas M., Nagymarosy A., Szegö E. Correlation of bio- and magnetostratigraphy of Badenian sequences from western and northern Hungary. Geologica Carpathica. 2012. № 63(3). P. 219-232. DOI: https://doi.org/10.2478/v10096-012-0019-1

Paulissen W., Luthi S., Grunert P., Coric S., Harzhauser M. Integrated high-resolution stratigraphy of a Middle to Late Miocene sedimentary sequence in the central part of the Vienna Basin. Geologica Carpathica. 2011. № 62(2). P. 155-169. DOI: 10.2478/v10096-011-0013-Z

Lirer F. et al. Astronomically forced teleconnection between Paratethyan and Mediterranean sediments during the Middle and Late Miocene. Palaeogeography, Palaeoclimatology, Palaeoecology. 2009. № 275(1-4). P. $1-13$. DOI10.1016/j.palaeo.2009.01.006

Palcu D.V., Tulbure M., Bartol M., Kouwenhoven T.J., Krijgsman W. The BadenianSarmatian Extinction Event in the Carpathian foredeep basin of Romania: paleogeographic changes in the Paratethys domain. Global and Planetary Change. 2015. 36 p. DOI: $10.1016 /$ j.gloplacha.2015.08.01

Hohenegger J., Rögl F., Coric S., Pervesler P., Lirer F., Roetzel R., Scholger R., Stingl K. The Styrian Basin: A key to the Middle Miocene (Badenian/Langhian) Central Paratethys transgressions. Austrian Journal of Earth Sciences. 2009. № 102(1). P. 102-132.

Piller W.E, Harzhauser M. The myth of the brackish Sarmatian Sea. Terra Nova. 2005. № 17. P. 450-455. DOI: 10.1111/j.1365-3121.2005.00632.x

Westerhold T., Torsten B., Röhl U. Middle to late Miocene oxygen isotope stratigraphy of ODP site 1085 (SE Atlantic): new constrains on Miocene climate variability and sea-level fluctuations. Palaeogeography, Palaeoclimatology, Palaeoecology. 2005. № 217(3-4). P. 205-222. DOI.org/10.1016/j.palaeo.2004.12.001

Приходько М.Г., Пономарьова Л.Д. Гелогічна будова Закарпатського прогину. Моногрфія. Київ : УкрДГРІ, 2018. 84 с. 


\subsection{Badenian/Sarmatian boundary in local aspect}

Within the West of Ukraine (Central Paratethys), the Badenian/Sarmatian boundary is an erosion regressive hiatus having different facial character. In most of the territory it is recorded by the undoing of beds $(3-8 \mathrm{~cm})$ of bentonite clay of redish color (formed during galmyrolysis of volcanic ash entering sedimentation basins by air), which does not contain fossils; limonitized sands, sandstones; mixed complexes of fauna (Buhliv beds); karstified surface (weathering bark) within the distribution of carbonate rocks (reef systems) or carbonated sandstones with formation of karstified origin relief $f^{52}$. This boundary is important - industrial hydrocarbon deposits are associated with it (Precarpathian foredeep (Ukraine, Poland)).

There is a problem in determining her absolute age. Thus, within the West of Ukraine (Transcarpathian foredeep) due to the study of volcanic cycles of Alpine orogenesi $^{53}$ three stages have been identified: 1 ) from tufs (sometimes lavas) rhyolite and the rhyodacit of Novoselitsa suite (and Tereshul layer) the Lower Badenian to andesites and their tufs of a Nizhnedorobrat subsuite of the Lower Sarmatian; 2) from tufs of the rhyolite of the Nizhnedorobrativ subsuite of the Lower Sarmatian (upper part of the Lower Sarmatian) to the andesites and their tufs of the Verhnedorobrat subsuite of the Upper Sarmatian; 3) from the rhyolites and their tufs of the tops of the Verhnedorobrat subsuite and the Lukiv suite (the Lower Sarmatian) to the andesites and their tufs by the Almas suite of the Middle Sarmatian. Volcanic products have been radiometric dating and their ages have been found to vary widely from $13,8 \pm 1,2$ to $9,49 \pm 0,60$ Ma. This became the basis for the isolation of the internal volcanic arc (within Berehovo), the transition strip (Mucachevo depression) and the external volcanic arc (Vygorlat-Gutin Ridge). Thus, within the internal volcanic arc, all volcanic structures are of Early Sarmatian age. The products of volcanic activities of acidic composition date from the Early Badenian bottoms of the Early Sarmatian and belong to the volcanoes of North-Eastern Hungary and North-Western Romania far enough from the places here. The acid composition volcanites found here in refer to the initial phase of the third stage. The absolute age is $13.8 \pm 1.2$ (dacite, diorite) to $12.86 \pm 0.7 \mathrm{Ma}$ (andesite).

\footnotetext{
52 Тузяк Я. Теоретичні і прикладні аспекти виявлення і проведення геологічних меж в осадово-шаруватих системах. Вісник Львівського університету. Сер. геолог. 2018. Вип. 32. С. 63-83.

Górka M., Studencka B., Jasionowski M., Hara U., Wysocka A., Poberezhskyy A. The Medobory Hills (Ukraine): Middle Miocene Reef Systems in the Parathetys, their biological diversity and lithofacies. Biuletyn Państwowego Instytutu Geologicznego. 2012. № 449. P. 147-174.

Hara U., Jasionowski M. The Early Sarmatian bryozoan Celleporina medoborensis sp. nov. from the Medobory reefs of west ern Ukraine (Central Paratethys). Geological Quarterly. 2012. № 56 (4). P. 895-906.

Peryt D., Jasionowski M. Sarmatian foraminiferal assemblages of cavern fillings in the Badenian reefs of Medobory (Polupaniwka, Western Ukraine). Biuletyn Państwowego Instytutu Geologicznego. 2012. № 449. 175-184.

${ }_{53}$ Приходько М.Г., Пономарьова Л.Д. Гелогічна будова Закарпатського прогину. Моногрфія. Київ : УкрДГРІ, 2018. 84 с.
} 


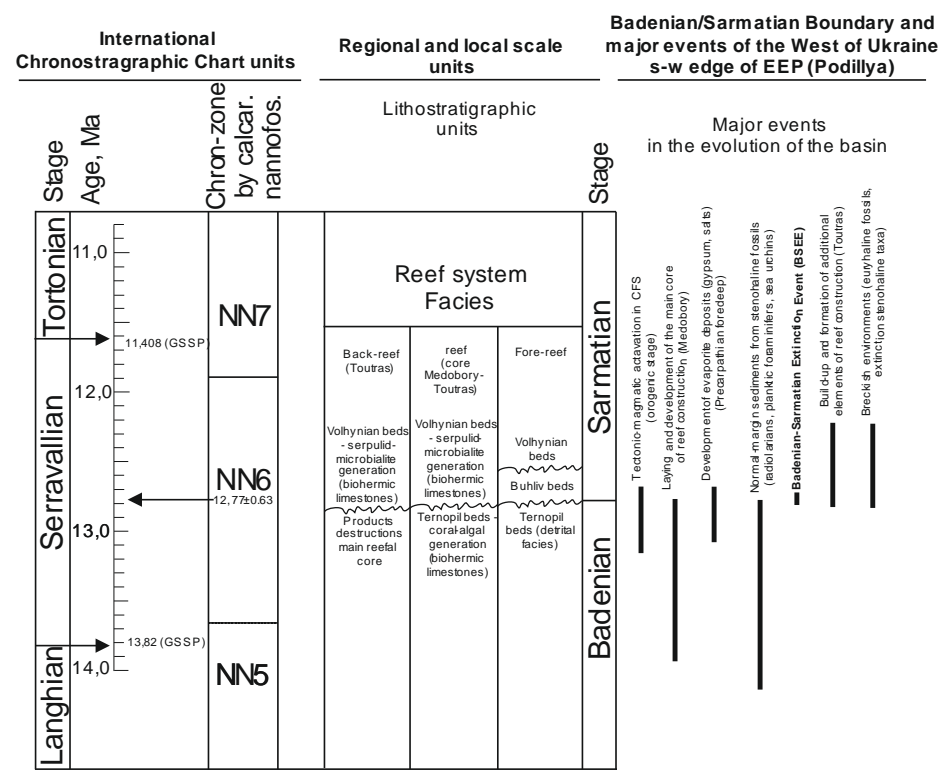

Fig. 19. Regional and local stratigraphy of Central Paratethys on the boundary of Badenian/Sarmatian and manifestation of the main events in the West of Ukraine (Podillya) (southern-western edge of EEP) and comparison with standard global chronostragraphy

The volcano-tectonic structures of the transition strip formed in the final phase of the first and second, as well as the third volcanic sub-stage, date from Early-, Middle Sarmatian, or Early Panonian age. In the direction from the inner to the outer volcanic arc there is a rejuvenation of volcanostructures from the Early Sarmatian to the Early Panonian. The absolute age is $12.77 \pm 0.63$ (rhyolite) to $10.28 \pm 0.43$ (andesito-basalt) Ma (acid-medium-base composition volcanites).

All known volcanostructures of the outer volcanic arc are formed in the final phase of the third and fourth volcanic sub-stages; their age is defined as Middle Sarmatian-Panonian. The absolute age is $11.5 \pm 0.5$ (granodiorite) to $9.49 \pm 0.60$ (andesite) $\mathrm{Ma}$ (acid-medium composition volcanites).

Assuming that the territory of the Transcarpathian foredeep was also an integral part of the Central Paratethys, and the processes that took place in the Carpato-Balkan folding system had an impact on its entire basin, the manifestation of events will wear a synchronous charakter. Thus, on the boundary of Badenian/Sarmatian in the Transcarpathian foredeep there were general raises for the whole Solotvin depression (final sedimentation), the first manifestation of processes of salt diapirizm. In the Mukachevo depression there was a powerful outbreak of volcanic activity in synchronous with it, which caused the formation of volcanic centers, volcanic eruptions and the formation of 
subvulcanic intrusions. Thus, the age of the Badenian/Sarmatian boundary will be $12.86 \pm 0.7-12.77 \pm 0.63 \mathrm{Ma}$.

Thus, at the Badenian/Sarmatian boundary there were events (Fig. 19), which contributed to the change of physical, chemical and biotic factors in the marine environment and in the sedimentary covering are determined by a complex of litho-sedimentation, biostratigraphical, paleoecological criteria.

\section{Paleoecological features and evolution of the Badenian/Sarmatian sedimentation basin}

During the Miocene, the territory of platform Ukraine is the edge of marine basins with coastal-marine conditions, characterized by sharp changes in the position of the coastline, its migration, formation of deposits in different-facial conditions and, as a result, uneven distribution of fauna, or its mixed complexes, unconformity geological boundaries between stratons. The studied complex of fossil organisms is characteristic of normal marine conditions. The complete absence of stenohaline biota may have been due to a change in seawater composition at the end of Badenian. These changes could be caused by tectonic events and the formation of the biogenic system of Medobory Reef (200-300 km long and 30-40 km wide, formed in the Late Badenian-Sarmatian), which separated the deep sea environment of the sea basin Precarpathian ${ }^{54}$ and contributed to the fall of the sea level and the elimination of connections from the Mediterranean/Indo-Pacific basins. As a result, residual marine waters were desalinated by atmospheric precipitation and continental river waters, which created conditions for the development of euryhaline biota. The restoration of further connections with tropical and subtropical sea basins has led to the entry of normal marine fauna into isolated epicontinental water bodies. For example, Ervilia and Mactra reflect shallow high-energy conditions, carbonate content, and subtropical climate. Similar conditions are needed for foraminifers, a reliable indicator, which are the findings of the plankton form Globorotalia menardi (Globorotalia characteristic of the deep sea part of the outer shelf (nerite zone) $)^{55}$ and other benthic species, which indicate the restoration of connections from the Mediterranean/Indo Pacific basins. The described situation is not limited to the territory of Podillya, as similar environments are known in Poland, Romania, Czech Republic, Croatia and Eastern Paratethys, which indicates

\footnotetext{
${ }^{54}$ Peryt D., Jasionowski M. Sarmatian foraminiferal assemblages of cavern fillings in the Badenian reefs of Medobory (Polupaniwka, Western Ukraine). Biuletyn Państwowego Instytutu Geologicznego. 2012. № 449. P. 175-184.

${ }_{55}$ Boudagher-Fadel M. Biostratigraphical and geological significance of planktonic foraminifera. Updated second edition. UCLPRESS. University College London, 2015. 298 p. DOI: $10.14324 / 111.9781910634257$

Hayward B.W., Le Coze F., Vachard D., Gross O. World Foraminifera Database. 2019. URL: http://www.marinespecies.org/aphia.php?p=taxdetails\&id=113497 on 2019-11-10.
} 
regional rather than local trends in the development of the Central Paratethys basin on the boundary of Badenian/Sarmatian ${ }^{56}$.

The accumulative organogenic-detrital layer, composed mainly of Badenian macrofossils, silicon nodules in the base of Buhliv beds and relics of Badenian fossils in the structure of microfaunistic complexes of Early Sarmatian, indicates erosion of Upper Badenian deposits, which is a sign of high-energy environment. Analysis of the systematic composition and degree of preservation of fossils (see Tab. 2, 3; Fig. 6) indicates decrease in salinity of the sea pool up to $18-16 \%{ }^{57}$, and existence in complexes of representatives of foraminifera the back-reef, reef and the fore-reef of facias points to existence of reef structures (bioherms) in Late Badenian. Oolite limestone, oncoids indicate a slowdown in

${ }^{56}$ Brânzilă M., Chirilă G., Jitaru M. Micropalaeontologic content of the Sarmatian from Southern Moldavian platform - a Backbulge depozone. Acta Palaeontologica Romaniae. 2011. V. 7. P. 45-59.

Filipescu S., Silye L. New Paratethyan biozones of planktonic foraminifera described from the Middle Miocene of the Transylvanian Basin (Romania). Geologica Carpathica, December 2008. № 59. 6. P. 537-544.

Fordinal K., Zágoršek K., Zlinská A. Early Sarmatian biota in the northern part of the Danube Basin (Slovakia). Geologica Carpathica. April 2006. № 57. 2. P. 123-130.

Górka M., Studencka B., Jasionowski M., Hara U., Wysocka A., Poberezhskyy A. The Medobory Hills (Ukraine): Middle Miocene Reef Systems in the Parathetys, their biological diversity and lithofacies. Biuletyn Państwowego Instytutu Geologicznego. 2012. № 449. P. 147-174.

Harzhauser M., Piller W.E. Integrated stratigraphy of the Sarmatian (Upper Middle Miocene) in the western Central Paratethys. Stratigraphy. 2004. № 1(1). P. 65-86.

Hohenegger J., Rögl F., Coric S., Pervesler P., Lirer F., Roetzel R., Scholger R., Stingl K. The Styrian Basin: A key to the Middle Miocene (Badenian/Langhian) Central Paratethys transgressions. Austrian Journal of Earth Sciences. 2009. № 102(1). P. 102-132.

Hohenegger J., Ćorić S., Wagreich M. Timing of the Middle Miocene Badenian Stage of the Central Paratethys. Geologica Carpathica. February 2014. № 65. 1. P. 55-66. DOI: 10.2478/geoca-2014-0004

Palcu D.V., Tulbure M., Bartol M., Kouwenhoven T.J., Krijgsman W. The Badenian-

Sarmatian Extinction Event in the Carpathian foredeep basin of Romania: paleogeographic changes in the Paratethys domain. Global and Planetary Change. 2015. 36 p. DOI: 10.1016/j.gloplacha.2015.08.01

Vrsaljko D., Pavelić D., Miknić M., Brkic M., Kovacic M., Hećimović I., HajekTadesse V., Avanić R., Kurtanjek N. Middle Miocene (Upper Badenian/Sarmatian) Palaeoecologv and Evolution of the Environments in the Area of Medvednica Mt. (North Croatia). Geologia Croatica. Zagreb. 2006. 59/1. P. 51-63.

Wysocka A., Radwanski A., Gorka M., Babel M., Radwanska U., Zlotnik M. The Middle Miocene of the Fore-Carpathian Basin (Poland, Ukraine and Moldova). Acta Geologica Polonica. 2016. Vol. 66. No. 3. P. 351-401. DOI: 10.1515/agp-2016-0017

${ }^{57}$ Harzhauser M., Piller W.E. Integrated stratigraphy of the Sarmatian (Upper Middle Miocene) in the western Central Paratethys. Stratigraphy. 2004. № 1(1). P. 65-86.

Palcu D.V., Tulbure M., Bartol M., Kouwenhoven T.J., Krijgsman W. The BadenianSarmatian Extinction Event in the Carpathian foredeep basin of Romania: paleogeographic changes in the Paratethys domain. Global and Planetary Change. 2015. 36 p. DOI: 10.1016/j.gloplacha.2015.08.01

Wysocka A., Radwanski A., Gorka M., Babel M., Radwanska U., Zlotnik M. The Middle Miocene of the Fore-Carpathian Basin (Poland, Ukraine and Moldova). Acta Geologica Polonica. 2016. Vol. 66. No. 3. P. 351-401. DOI: 10.1515/agp-2016-0017

Piller W.E, Harzhauser M. The myth of the brackish Sarmatian Sea. Terra Nova. 2005. № 17. P. 450-455. DOI: 10.1111/j.1365-3121.2005.00632.x 
the circulation of water masses due to the existence of sand bars ${ }^{58}$, which, at the same time as tectonic ones, have become one of the main factors in the termination of connections with the Mediterranean and Eastern Paratethys basins until the end of the Sarmatian. Ecological conditions (fresh water intake, active circulation and high oxygen content) have led to the development of fauna with signs of euryhalicity, which is diverse in systematic composition (foraminifera, molluscs, ostracodes, bryozoans, serpulids).

\section{Genesis conditions of the Buhliv beds}

In order to understand the formation of deposits of the Bugliv beds, it is necessary to consider the geological (structurally)-geomorphological situation that existed at that time within the territory of Podillya (Fig. 20). An outstanding event of the Middle Miocene was the laying and development of organogenic constructions ${ }^{59}$ of the type of reefs and bioherms. Active tectonic-magmatic activity in the Carpathians together with newly formed structures influenced the sedimentation environment as a whole Paratethys ${ }^{60}$ and caused a complete change of its physical, chemical

${ }^{58}$ Кульчицкий Я.О.. Кульчицкий А.Я. Двустворчатые и брюхоногие моллюски из сармата Предкарпатского и Закарпатского прогибов и их стратиграфическое значение. Палеонтол. сборник. 1983. № 20. С. 50-58.

Карпенко Н.I. Рельєф морських берегів : навч. посібник. Львів : Видавничий центр ЛНУ імені Івана Франка, 2009. 308 с.

Москалюк К.Л. Аналіз рельєфу Подільських Товтр для оптимізації природокористування : автореф. ... канд. географ. наук : 11.00 .04 «Геоморфологія і палеогеографія». Львів, 2009. 23 с.

59 Кульчицкий Я.О., Кульчицкий А.Я. Двустворчатые и брюхоногие моллюски из сармата Предкарпатского и Закарпатского прогибов и их стратиграфическое значение. Палеонтол. сборник. 1983. № 20. С. 50-58.

Карпенко Н.І. РельєФ морських берегів : навч. посібник. Львів : Видавничий центр ЛНУ імені Івана Франка, 2009. 308 с.

Маслов В.П. Ископаемые багряные водоросли СССР и их связь с фациями. Издво АН СССР. Москва. 1962. 221 с. (Тр. Геологич. ин-та. Вып. 53).

Москалюк К.Л. Аналіз рельєфу Подільських Товтр для оптимізації природокористування : автореф. ... канд. географ. наук : 11.00 .04 «Геоморфологія і палеогеографія». Львів, 2009. 23 с.

Górka M., Studencka B., Jasionowski M., Hara U., Wysocka A., Poberezhskyy A. The Medobory Hills (Ukraine): Middle Miocene Reef Systems in the Parathetys, their biological diversity and lithofacies. Biuletyn Państwowego Instytutu Geologicznego. 2012. № 449. P. 147-174.

Hara U., Jasionowski M. The Early Sarmatian bryozoan Celleporina medoborensis sp. nov. from the Medobory reefs of west ern Ukraine (Central Paratethys). Geological Quarterly. 2012.56 (4). P. 895-906.

${ }^{60}$ Приходько М.Г., Пономарьова Л.Д. Гелогічна будова Закарпатського прогину. Монографія. Київ : УкрДГРІ, 2018. 84 с.

Brânzilă M., Chirilă G., Jitaru M. Micropalaeontologic content of the Sarmatian from Southern Moldavian platform - a Backbulge depozone. Acta Palaeontologica Romaniae. 2011. V. 7. P. 45-59. 
and biotic factors. The physical effect was on the configuration of the marine basin, the termination/resumption of linking with Eastern Paratethys and the Mediterranean/Indo Pacific basin, which in turn led to the change of the normal marine regime to brackish (mixo-mesohaline) water (chemical factor), and this affected the biota complexes (biotic factor) - the disappearance of stenohaline taxa (planktic foraminifers, radiolarians, corals, echinoderms) and development of endemic species.

De Leeuw A., Filipescu S., Matenco L., Krijgsman W., Kuiper K., Stoica M. Paleomagnetic and chronostratigraphic constraints on the middle to late Miocene evolution of the Transylvanian basin (Romania): Implications for central Paratethys stratigraphy and emplacement of the Tisza-Dacia plate. Global and Planetary Change. 2013. № 103(1). P. 82-98. DOI:10.1016/j.gloplacha.2012.04.008

Gebhardt H., Zorn I., Roetzel R. The initial phase of the early Sarmatian (Middle Miocene) transgression. Foraminiferal and ostracod assemblages from an incised valley fill in the Molasse Basin of Lower Austria. Austrian Journal of Earth Sciences. 2009. Vol. 102/2. P. 100-119.

Harzhauser M., Piller W.E. Integrated stratigraphy of the Sarmatian (Upper Middle Miocene) in the western Central Paratethys. Stratigraphy. 2004. № 1(1). P. 65-86.

Hohenegger J., Rögl F., Coric S., Pervesler P., Lirer F., Roetzel R., Scholger R., Stingl K. The Styrian Basin: A key to the Middle Miocene (Badenian/Langhian) Central Paratethys transgressions. Austrian Journal of Earth Sciences. 2009. № 102(1). P. 102-132.

Palcu D.V., Tulbure M., Bartol M., Kouwenhoven T.J., Krijgsman W. The BadenianSarmatian Extinction Event in the Carpathian foredeep basin of Romania: paleogeographic changes in the Paratethys domain. Global and Planetary Change. 2015. 36 p. DOI: 10.1016/j.gloplacha.2015.08.01

Paulissen W., Luthi S., Grunert P., Coric S., Harzhauser M. Integrated high-resolution stratigraphy of a Middle to Late Miocene sedimentary sequence in the central part of the Vienna Basin. Geologica Carpathica. 2011. № 62(2). P. 155-169. DOI: 10.2478/v10096011-0013-z

Piller W.E, Harzhauser M. The myth of the brackish Sarmatian Sea. Terra Nova. 2005. № 17. P. 450-455. DOI: 10.1111/j.1365-3121.2005.00632.x

Popov S.V., Shcherba I., Ilyina L., Nevesskaya L., Paramonova N., Khondkarian S., Magyar I. Late Miocene to Pliocene palaeogeography of the Paratethys and its relation to the Mediterranean. Palaeogeography, Palaeoclimatology, Palaeoecology. 2006. № 238 (1-4). P. 91-106. DOI:10.1016/j.palaeo.2006.03.020

Rögl F., Spezzaferri S. Foraminiferal paleoecology and biostratigraphy of the Mühlbach section (Gaindorf Formation, Lower Badenian), Lower Austria. Ann. Naturhist. Mus. Wien. Mai. 2003. № 104. P. 23-75.

Rögl F., Steininger F.F. Vom Zerfall der Tethys zu Mediterran und Paratethys. Die Neogene Palaeogeographie und Palinspastik des zirkummediterranen Raumes. Annales Naturhistorischen Museum Wien. 1983. № 85. P. 135-163.

Vrsaljko D., Pavelić D., Miknić M., Brkic M., Kovacic M., Hećimović I., HajekTadesse V., Avanić R., Kurtanjek N. Middle Miocene (Upper Badenian/Sarmatian) Palaeoecologv and Evolution of the Environments in the Area of Medvednica Mt. (North Croatia). Geologia Croatica. Zagreb. 2006. № 59/1. P. 51-63. 


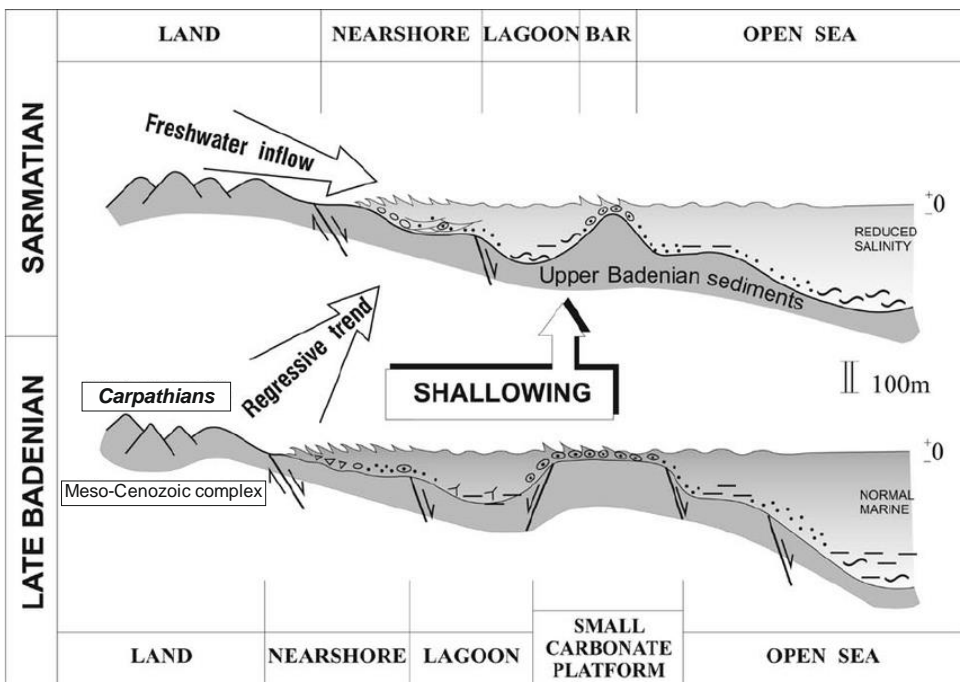

\section{Fig. 20. Model of environment evolution: Badenian-Sarmatian sedimentation(idealized profile) by Vrsaljko D. et al. ${ }^{61}$}

\subsection{Geological and geomorphological structure Medobory-Toutras}

Structure, age, lithofacial composition, complexes of fossil (reef-building organisms and reef-dwellers organisms), morphology of structural elements of the biogenic of the Middle Miocene fossil structure are illuminated in a number of works of domestic ${ }^{62}$ and foreign researchers ${ }^{63}$. We would like to

${ }^{61}$ Тузяк Я. Подія на границі баденій/сармат в межах Поділля: палеогеографічні та палеоекологічні зміни в Центральному Паратетисі. Здобутки та перспективи розвитку геологічної науки в Україні : збірник тез наукової конференції, присвяченої 50-річчю Інституту геохімії, мінералогії та рудоутворення імені М.П. Семененка, Київ, 14-16 травня 2019 р. У 2-х томах. НАН України, Ін-т геохімії, мінералогії та рудоутворення ім. М.П. Семененка. Київ. 2019. Т. 2. С. 229-231.

62 Карпенко Н.I. Рельєф морських берегів : навч. посібник. Львів : Видавничий центр ЛНУ імені Івана Франка, 2009. 308 с.

Ласкарев В.Д. О сарматских отложениях, некоторых мест Волынской губернии. 3ап. Новорос. о-ва естествоиспытателей. 1897. № 21. Вып. 2. С. 89-115.

Маслов В.П. Ископаемые багряные водоросли СССР и их связь с фациями. Изд-во АН СССР. Москва, 1962. 221 с. (Тр. Геологич. ин-та. Вып. 53).

${ }^{63}$ Górka M., Studencka B., Jasionowski M., Hara U., Wysocka A., Poberezhskyy A. The Medobory Hills (Ukraine): Middle Miocene Reef Systems in the Parathetys, their biological diversity and lithofacies. Biuletyn Państwowego Instytutu Geologicznego. 2012. № 449. P. 147-174.

Hara U., Jasionowski M. The Early Sarmatian bryozoan Celleporina medoborensis sp. nov. from the Medobory reefs of west ern Ukraine (Central Paratethys). Geological Quarterly. 2012. № 56 (4). P. 895-906. 
focus on some achievements in the study of this structure and supplement the results with new data and our own views on this issue. For this purpose we analyzed the models of structure and classification of modern ${ }^{64}$ and fossil ${ }^{65}$ reefs. For detailed study of Medobory and Toutras beds we take labor as a basis ${ }^{66}$.

We consider it advisable to consider the model of the structure of reef systems, morphology of their structural elements, types of modern reefs and peculiarities of their development stages in order to understand the structure of the fossil reef range Medobory and Toutras (Fig. 21, 22) in order to determine the processes of their laying, evolution of development and role as sources of sedimentary material supply for formation of new geological bodies and reservoir for localization of hydrocarbon deposits.

At the present stage, there are different approaches to the classification of biogenic structures: on the genesis of biogenic bodies; on the structuralmorphological building (the structure of organogenic bodies in the plan and in section), on systematic structure of reef-building organisms. However, none of them fully reveals this problem. At the same time, the analysis of the structure of modern reefs can lead us to clarify the issue, but in no case to a complete solution and serve us only as an example, not as a standard to which researchers equate their observations.

Peryt D., Jasionowski M. Sarmatian foraminiferal assemblages of cavern fillings in the Badenian reefs of Medobory (Polupaniwka, Western Ukraine). Biuletyn Państwowego Instytutu Geologicznego. 2012. № 449. P. 175-184.

${ }_{64}$ Карпенко Н.I. РельєФ морських берегів : навч. посібник. Львів : Видавничий центр ЛНУ імені Івана Франка, 2009. 308 с. $453 \mathrm{c}$.

Жирков И.А. Жизнь на дне. Биогеография и биоэкология бентоса. Москва, 2010.

Рифогенные формации и рифы в эволюции биосферы / Отв. ред. С.В. Рожнов. Серия «Гео-биологические процессы в прошлом». Москва, ПИН РАН, 2011. 228 с.

Шепард Ф.П. Морская геология 3-е изд. Ленинград : Недра, 1976. 488 с.

Chapter 15 Animals of the benthic environment. URL: https://slideplayer.com/ slide/4022004/.

${ }^{65}$ Рифогенные формации и рифы в эволюции биосферы. Отв. ред. С.В. Рожнов. Серия «Гео-биологические процессы в прошлом». Москва, ПИН РАН, 2011. 228 с.

Максимович Г.А., Быков В.Н. Карст карбонатных нефтегазоносных толщ. Пермский ун-т, 1978. 96 с.

Wiens H.J. Atoll environment and ecologv. L.: Yale Universitv Press. 1962. 532 p.

${ }^{66}$ Карпенко Н.І. Рельєф морських берегів : навч. посібник. Львів : Видавничий центр ЛНУ імені Івана Франка, 2009. 308 с.

Маслов В.П. Ископаемые багряные водоросли СССР и их связь с фациями. Изд-во АН СССР. Москва, 1962. 221 с. (Тр. Геологич. ин-та. Вып. 53).

Górka M., Studencka B., Jasionowski M., Hara U., Wysocka A., Poberezhskyy A. The Medobory Hills (Ukraine): Middle Miocene Reef Systems in the Parathetys, their biological diversity and lithofacies. Biuletyn Państwowego Instytutu Geologicznego. 2012. № 449. Р. 147-174. $453 \mathrm{c}$.

Жирков И.А. Жизнь на дне. Биогеография и биоэкология бентоса. Москва, 2010.

Москалюк К.Л. Аналіз рельєфу Подільських Товтр для оптимізації природокористування : автореф. ... канд. географ. наук : 11.00 .04 «Геоморфологія і палеогеографія». Львів, 2009. 23 с. 

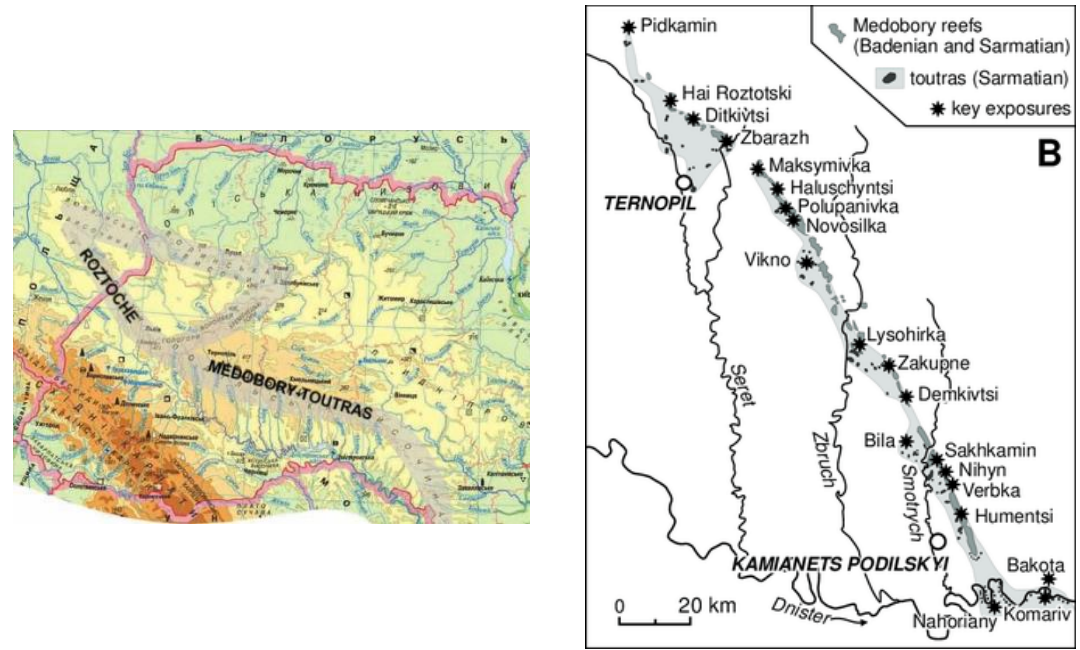

Fig. 21. Reef structure Medobory and Toutras within Ukraine

To begin with, we will highlight some of the main achievements in the field of study of the reef structure Medobory and Toutras (Fig. 20, 21) in order to show the author's idea of their structure and development in accordance with these models and to obtain his own research results.

1. Medobory and Toutras are a fossil reef structure of Middle Miocene age, composed of two morphological elements - the main belt (Medobory) and superstructured bioherms (Toutras), surrounding the north-eastern periphery of Paratethys, laid down on the lowered south-west edge of the East European Platform. It has a clear reflection in geomorphology (relief), extends over $300 \mathrm{~km}$, known not only on the territory of Ukraine, but also outside it - Moldova, Romania. The width of the reefal zone (main belt and side Toutras) varies from 5-8 to $15-30 \mathrm{~km}$. The size of reef bodies increases to the south and within Ukraine the thickness of biogerms reaches $60-65 \mathrm{~m}$. For massives of the main belt there is a wide (from 200-300 to 500-600 m) aligned vertex surface with almost the same absolute heights. The main Medobory Hills and lateral Toutras differ in morphological characteristics, which clearly stand out in the relief of Podollian structurally denudational elevation. The absolute heights of the main range decrease from north-west to south-east.

2. The selected morphological elements of the main belt and lateral Toutras differ in structure, lithofacial features, fossil complexes (by polish researchers there are two generations ${ }^{1}$ ), geological age, structural plan of laying and development. 
3. For Medobory (main belt) asymmetric structure is characteristic: short and steep south-west slope (up to $35-40^{\circ}$ ) and north-east long and shallow (up to $10-15^{\circ}$ ).

4. Geological age. The reefs of Medobory Hills consists of lithofacies and biotic associations of two generations - Late Badenian, among which organodetrital and biohermal dominate (their main rock-forming components were coralline algae, hermatypic corals, rich and diverse invertebrates - foraminifers, molluscs, bryozoans, ostracods); Early Sarmatian reefs are built by microbialites, the main components of which are serpulids and microbialites (bryozoan-serpulids limestone) with numerous but uniform taxonomic composition of invertebrates.

5. The most important elements of the reefal structures of Late Badenian are encrusting red algae of the family Corallinaceae, organisms by residents of reef sedentary gastropods of the family Vermetidae. Due to their number of taxa, facie (especially in the area of Roztocze) appears in the geological literature under the name algae vermetus reefs (Pisera, 1985). Hermatypic corals are widespread - a major hallmark of Medobory reefs and Roztocze within which corals have not been detected. In addition, individual parts of the reefs are locally constructed from numerous members of Bryozoa, Gastropoda, and/or oysters. Another group of reef-building organisms is represented by taxonomically rich and diverse associations of bivalves, marine gastropods, crustaceans (crabs), foraminifers, annelids, bryozoans and echinoderms (sea urchins). Almost all organisms with primary aragonite shells were dissolved as a result of postsedimentary diagenesis and are now preserved in the form of moulds and/or imprints (sometimes traces of decalcitination (cavities on the site of buried skeletal remains due to leaching and dissolution). Most often it concerns molluscs, the shells of which (except of calcite shells of oysters, scallops and related taxa) are almost always completely dissolved. These dissolution processes are due to atmospheric precipitation, which due to volcanic eruptions has been aggressive ("acid rains").

6. The oraganofacial generation of Badenian/Sarmatian is separated by a clear geological boundary - an eroded surface of dissenting type with signs of karstified surface (weathering). Destruction products (rhodoites, calcarites, calcirudites) of the Late Badenian biogenic body fill cavities, cracks, funnel, pockets of reefs themselves, as well as found in the foot of reef structures, the number of which grows with distance from the sources of destruction (reefs) themselves. The Early Sarmatian reefs usually build up the eroded surface of Late Badenian, reaching large thickness on the southwestern slopes of the Medobory.

7. Bioherms (Toutras) are cone-shaped hills, 360-325 $\mathrm{m}$ high, the chain of which on separate sections forms ridges, which are located perpendicular to the direction of extension of the main range. They either build up or border the main range of Medobory Hills from the south-west slope and 
formed in a back-reef (lagoon) basin (Early Sarmatian). Small biogerms are also common within the northeast slope of Medobory Hills.

8. The geological age of Toutras - is composed by one generation of the litho-facies of the Lower Sarmatian - serpulid-microbialite limestone, the main components of which are micrites forming microbialites and small serpulids (tube diameter about $1 \mathrm{~mm}$, length up to several centimeters), possibly of the genus Hydroides Gunnerus (Koroluk, 1952; Pisera, 1978) ${ }^{67}$. Other litho-facias play a subordinate role in Lower Sarmatian reefs. In biotic associations of Early Sarmatian there are two groups: the first - organisms of rifworkers (encrusting organisms - coralline algae, sessile foraminifers (nubecularids), multilamelar bryozoans of the genus Schizoporella Hincks) and the second - organisms of inhabitants (bivalves, several taxa of gastropods, bryozoans, foraminifers and ostracods), who do not take part in the construction of the reef framework. Cavities, cracks in reef deposits of the Lower Sarmatian are filled with other lithofacies - beds of marls and organogenically-detrital limestone. They gradually move into open marine clay layers (s-w Medobory) or into clay/sandstone and oolite facies of the back-reef ("lagoon") zone.

9. Paleoenvironment conditions. The outstanding event of the Cenozoic, the Middle Miocene in particular, was the rapid development of reefs not only within the Mediterranean, but also in Paratethys, located in the north. Since coralline algae were the main reef framework, the shape of the bodies they formed was in the form of layers (sidewalks, cornice, crust, kayaks, rollers, etc. $)^{68}$.

${ }^{67}$ Королюк И.К. Подольские Толтры и vсловия их образования. Труды Ин-ma геол. наук АН СССР. Сер. геол. 1952. Вып. 110. № 56. 120 с.

Маслов В.П. Ископаемые багряные водоросли СССР и их связь с фациями. Изд-во АН СССР. Москва, 1962. 221 с. (Тр. Геологич. ин-та. Вып. 53).

${ }^{68}$ Королюк И.К. Подольские Толтры и условия их образования. Труды Ин-та геол. наук АН СССР. Сер. геол. 1952. Вып. 110. № 56. 120 с.

Маслов В.П. Ископаемые багряные водоросли СССР и их связь с фациями. Изд-во АН СССР. Москва, 1962. 221 с. (Тр. Геологич. ин-та. Вып. 53).

Górka M., Studencka B., Jasionowski M., Hara U., Wysocka A., Poberezhskyy A. The Medobory Hills (Ukraine): Middle Miocene Reef Systems in the Parathetys, their biological diversity and lithofacies. Biuletyn Państwowego Instytutu Geologicznego. 2012. № 449. P. 147-174. 


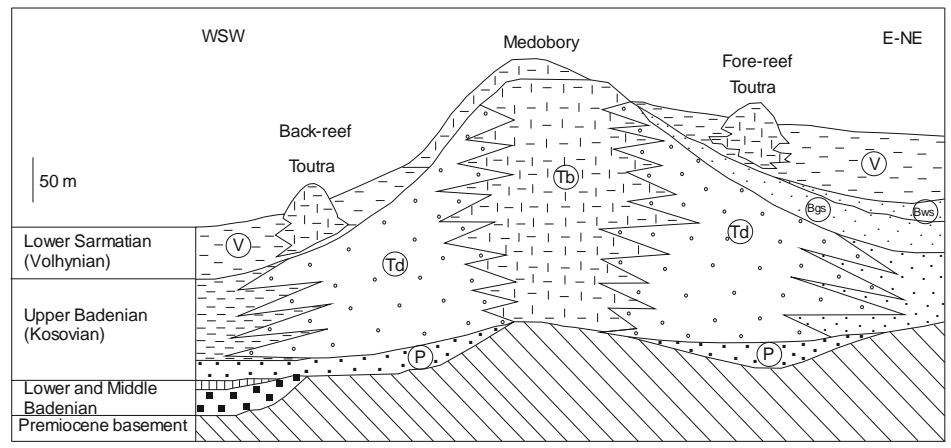

Fig. 22. Schematic geological (structural and age) model of Medobory core structure (cross section). Spatial ratio of biohermal facies of Medobory Hills and Toutras, details of their lithology and main structurally lithological units

Legend: P - Pidhirtsi Beds; Tb-Ternopil Beds (biohermic facies); Td-Ternopil Beds (detrital facies); Bgs - Buhliv Beds (glauconite sands); Bws - Buhliv Beds (white sands); V-Volhyn Beds (biohermic facies) by Górka M. et al., $2012^{69}$ and Wysocka A. et al., $2016^{70}$

Among all known reefs of Paratethys organogenic structures of Medobory Hills have the largest dimensions (Fig. 20, 21) ${ }^{71}$. The relatively small number of corals is probably due to the location of the region outside the tropical belt. Coral algae reefs of Medobory were formed in shallow water (lithoraly, subliteraly areas) and relatively warm waters (warming of water masses may also have been carried out as a result of the activity of volcanoes (Late Badenian/Early Sarmatian) located nearby, and the entry into the atmosphere of a large amount of carbon dioxide $\left(\mathrm{CO}_{2}\right)$ and other compounds (Transcarpathan foredeep ${ }^{72}$ ), normally salty conditions of the

${ }^{69}$ Górka M., Studencka B., Jasionowski M., Hara U., Wysocka A., Poberezhskyy A. The Medobory Hills (Ukraine): Middle Miocene Reef Systems in the Parathetys, their biological diversity and lithofacies. Biuletyn Państwowego Instytutu Geologicznego. 2012. № 449. P. 147-174.

${ }^{70}$ Wysocka A., Radwanski A., Gorka M., Babel M., Radwanska U., Zlotnik M. The Middle Miocene of the Fore-Carpathian Basin (Poland, Ukraine and Moldova). Acta Geologica Polonica. 2016. Vol. 66. No. 3. P. 351-401. DOI: 10.1515/agp-2016-0017

${ }^{71}$ Górka M., Studencka B., Jasionowski M., Hara U., Wysocka A., Poberezhskyy A. The Medobory Hills (Ukraine): Middle Miocene Reef Systems in the Parathetys, their biological diversity and lithofacies. Biuletyn Państwowego Instytutu Geologicznego. 2012. № 449. P. 147-174.

Wysocka A., Radwanski A., Gorka M., Babel M., Radwanska U., Zlotnik M. The Middle Miocene of the Fore-Carpathian Basin (Poland, Ukraine and Moldova). Acta Geologica Polonica. 2016. Vol. 66. No. 3. P. 351-401. DOI: 10.1515/agp-2016-0017

${ }_{72}$ Приходько М.Г., Пономарьова Л.Д. Гелогічна будова Закарпатського прогину. Монографія. Київ : УкрДГРІ, 2018. 84 с. 
high sea and high energy hydrodynamics of the environment. The presence of corals and other heat-loving taxa in the Medobory reefs indicates that the waters in which they lived were warmer than those of the Roztocze (Poland, Ukraine). In contrast, in areas in the south (modern Hungary and Bulgaria), corals play an important role in the construction of reef structures (which proves the close localization of volcanoes and the accumulation of $\mathrm{CO}_{2}$ reefs from the atmosphere ${ }^{73}$ ). As a result of the termination/resumption of links between Paratethys and the Mediterranean at the end of Badenian at the beginning of Sarmatian, the Paratethys sea basin has become a mixomesohaline (half-marine) basin. The development of Early Sarmatian serpulid-microbialite reefs was due to specific environmental conditions during this time.

We also believe that the influence on the environment of formation of reefs Sarmatian had directly biogenic structure Medobory. Its appearance divided the Central Paratethys basin into two parts: the north-eastern, adjacent to the EEP and, accordingly, breckish (due to the mixing of residual sea waters with fresh continental (river) waters and atmospheric precipitation); and the south-west adjacent to the Precarpathian foredeep and possibly more salty, which led to the construction of Toutras organogenic serpulid-microbialite structures on the south-west side. Seawater inputs to the breckish (north-east) basin can be attributed to storm activity and transfusion due to low or destroyed reef peaks, and corridor-straits between reef bodies. Another feature of the impossibility of forming Lower Sarmatian Toutras structures on the north-east side is the withdrawal of the reef system to the day surface, under which it is impossible to grow further.

\subsection{History of evolution of the reef system of Medobory-Toutras}

So, based on the analysis of the above-described models Medobory is a Late Badenian-Sarmatian biogenic structure - a barrier reef of the edge type. It is laid down in the zone of tectonic immersion of the shore (immersion of the South-West edge of EEP under the Carpathian folded massif), with the subsequent structure of the superstructure in height and formation of additional elements (Early Sarmatian generation of reefs - Toutras). Tectonic movements in the Carpato-Balkan folded structure on the boundary of Badenian/Sarmatian led to the withdrawal to the day surface of the Medobors belt, which contributed to its destruction (eroded and karstified surface with numerous erosional fissures, cracks, cavities, cavern, laces, pockets, etc. ${ }^{74}$ ). The following immersion caused the formation of lagoons in the middle and the appearance of bioherms (Toutras) - intra-lagoon reefs in

73 Жирков И.А. Жизнь на дне. Биогеография и биоэкология бентоса. Москва, 2010. 453 c.

${ }^{74}$ Wysocka A., Radwanski A., Gorka M., Babel M., Radwanska U., Zlotnik M. The Middle Miocene of the Fore-Carpathian Basin (Poland, Ukraine and Moldova). Acta Geologica Polonica. 2016. Vol. 66. No. 3. P. 351-401. DOI: 10.1515/agp-2016-0017 
the form of peaks and a hills with steep slopes 340-360 $\mathrm{m}$ in height, rising from the bottom of the lagoon (serpulid-microbialite generation of bioherms of Early Sarmatian). They encircle the south-west slope of the main range of Medobory, located perpendicular to its extension and formed in the backreef (lagoon) basin. The reef hills served as a barrier to mixing waters. Given the localization of the reefs, it can be assumed that in the Sarmatian the south-west (lagoon) part of the sea basin was somewhat salty compared to the north-east (outer). The main source of the formation of the Buhliv beds was the destruction products of the reef structure and their accumulation in the deposition zones, which are the fore-reef platform located in the northeast and bordering the land of the EEP. On structure, the building and morphology the reef Medobory system is similar to Ishimbayevsky reefs of the Permian age of the Preuralian foredeep, chains the Upper Devonian of reefs Rimbi-Ledyuk-Clyde the Western-Canadian pool, etc.

Thus, in the history of the Carpathian folding system / Carpathian mobile belt (CFS/CMB), several periods (stages) of the existence of reefal systems can be distinguished.

The first of these began in Early Badenian and continued until Late Badenian. This series of reefal bodies is connected with the rifting of the edge of the East European Platform (EEP) and the formation in its southwest of the Main Carpathian Rift (MCR), and divided the two main structurally-tectonic elements - monolithic craton EEP and the diverse area of the CFS. Biogenic structures (BS) of the Middle Miocene are timed to the north-east board of the MCR. In the structure of the reef system there is an age zonal in longitudinal and transverse directions. Thus, according to the longitudinal extension, the oldest elements of the reef system are in the north-west (Roztocze) - Naraiv beds, and the younger - south-east (Medobory and Toutras) - Ternopil beds (Fig. 21, 22). Within the southeastern extension there is a transverse zonal, with the oldest of them (the main core of Medobory) located in the north-east of the submerged part of the platform, and significantly younger generation of reefs (additional biogenic bodies of Toutras) markedly shifted to the south-west (towards the Precarpathian foredeep). Given the facial aspect of the laying of reefal systems, they occur at the boundary of coastal substantially carbonate facias and deeper water deposits (clay, silical involving pelitomorphic limestone and volcanic rocks) of the rift zone. In our case, the Middle Miocene reefal structure was laid down and dismembered the deep-sea basin of the Precarpathian foredeep (modern external Bilche-Volytsya Zone) from the coastal (epicontinental) located on the south-western edge of the EEP. The boundaries of all facial zones of this period were oriented parallel to the Carpathians.

75 Максимович Г.А., Быков В.Н. Карст карбонатных нефтегазоносных толщ. Пермский ун-т, 1978. 96 с.

Рифогенные формации и рифы в эволюции биосферы / Отв. ред. С.В. Рожнов. Серия «Гео-биологические процессы в прошлом». Москва, ПИН РАН, 2011. 228 с. 
The second generation of BS is connected with Late Badenian and its emergence is defined tektono-magmatic activization in Carpathian-Balkan folded system (formation Precarpathian oil-and-gas province), migration of the sea pool on the south-east of EEP. At the end of the Late Badenian, a system of raises and deflections with different sedimentation settings emerged in this vast area. Within its raised parts carbonate layers were formed, in lowered zones - clay, marl formations. Organogenic constructions of various types are timed to edge zones of raises. It should be noted that in the Late Badenian facies were placed tiled ${ }^{76}$, but their general orientation with respect to the CFS did not change - they continued to lie parallel to the Carpathians. The laying of BS was controlled by the tectonic regime, which contributed to their considerable variety - represented by various organogenic and organogenically detrital facies.

The third generation of BS originated during the orogenesis stage in CFS (Late Badenian - Early Sarmatian). Their laying takes place in two zones within the main range (core) of Medobory, where they increase the reef sign in height, and the appearance of additional structures between the reef core and the Precarpathian foredeep, which contributes to the increase of the width of the reef system. They are oriented perpendicular to the main reefal hills. They are characterized by changes in the encrusting organisms and morphology of biohermic bodies. Manifestation of facial-ecological zonation with recognition of fore-reef, reef and back-reef facial areas is characteristic of this generation.

The initial and final stages of the reef formation are represented by structures such as biogerms and biostroms. The main phase of the reef formation covers Late Badenian - Early Sarmatian, during this period formed thickness (up to 300-350 $\mathrm{m}$ in each stage) subshirly oriented reefal massives, with clear facial ecological zonal. Reefs of this age segment a are characterized by a considerable variety of facies of carbonate composition and rich taxonomic composition of fossils.

The study of reef systems is of important applied (economic) importance, because by analogy with other fossil reef systems ${ }^{77}$ can be considered as an important reservoir of accumulation and localization of industrial hydrocarbon deposits, which gives this problem a relevant importance.

\section{CONCLUSIONS}

Preliminary studies of the Buhliv beds (on the example of the section of Vanzhuliv village) provided an opportunity to clarify the discussion questions concerning the geological age, volume and stratigraphic position in the RSS and ICC, to determine their genesis and paleoecological conditions of education.

\footnotetext{
${ }^{76}$ Маслов В.П. Ископаемые багряные водоросли СССР и их связь с фациями. Изд-во АН СССР. Москва, 1962. 221 с. (Тр. Геологич. ин-та. Вып. 53).

77 Максимович Г.А., Быков В.Н. Карст карбонатных нефтегазоносных толщ. Пермский ун-т, 1978. 96 с.
} 
1. Based on the identification and study of the systematic composition of microfossils (foraminifers, corals, molluscs, bryozoans, ostracods, polychaeta) and the degree of preservation of their remains, the characteristic of this straton has been significantly supplemented and the results previously obtained have been confirmed.

2. Stratigraphic, biostratigraphic, facial and paleoecological criteria of Buhliv beds are defined.

3. The microfaunistic complexes, like the macrofossils association, are composed of mixed remains (different age and heterofacial) type.

4. Buhliv beds can be considered in two aspects - as local stratigraphic unit (stratotype of beds) and regional - Badenian/Sarmatian boundary Badenian-Sarmatian Extension Event (BSEE) of typical marine (stenohaline) representatives - planktic foraminifers, radiolarians, corals, sea urchins $^{78}$.

5. As a geomorpholic-geological structure - the reefs of MedoboryToutras at the same time with the orogenic stage in the Carpathian folding system played an important role in the isolation of Central Paratethys from the adjacent Mediterranean / Indo-Pacific basins, their formation increased the sedimentary case of Neogene and became the source of formation of new geological bodies, in particular Buhliv beds. It has been explained that they were formed in the conditions of fore-reef facie as a result of the products of destruction of the biogenic structure.

6. The study of microfossils from the Buhliv beds and the analysis of the structure of the reef system contributed to the determination of transverse, longitudinal and vertical zonation. So, in the cross direction allocation of facial-ecological zones - fore-reef, reef and back-reef facias is traced. In the longitudinal direction (from north-west to south-east) rejuvenation and complications of the structure of reef construction. In the vertical direction (evolution in time) - identification of three stages of reef systems development, which differ in shape and type of biogenic bodies, change of organisms of reef-builders and organisms-inhabitants and age limits of laying and development of corresponding stages of reefs - from simple to more complex. The evolution of reef systems is directly related to the development of reef zones.

78 Бугловские слои миоцена. Материалы Всесоюзного симпозиума. Львов, 6-16 сентября 1966 г. Киев : Наук. думка, 1970. 279 с.

Ласкарев В.Д. О сарматских отложениях, некоторых мест Волынской губернии. 3ап. Новорос. о-ва естествоиспьтателей. 1897. № 21. Вып. 2. С. 89-115.

Ласкарев В.Д. Фауна бугловских слоев Волыни. Санкт-Петербург, 1903. 126 с. (Тр. Геол. ком. Нов. сер. Вып. 5).

Тузяк Я. Буглівські верстви (міоцен, неоген) Тернопільської області комплексна геологічна пам'ятка природи: стан охорони i перспективи рекреаційного використання. Мінерально-сировинні багатства Украӥни: иляхи оптимального використання. Матеріали восьмої науково-практичної конференції, 4 жовтня 2019 р., смт Хорошів. Київ, 2019. С. 122-132. 
The work was done as a result of cooperation with Polish Geological Institute PAN (Krakow, Poland). The author is grateful to the Doctor of Geological Sciences P. Gedl for his assistance in conducting research.

\section{SUMMARY}

Comments are given on paleontology, stratigraphy, paleoecology, paleogeography and conditions of Buhliv beds formation (Neogen, Miocene) Podillya (Western Ukraine), which long caused discussions in ukrainian and polish scientific environments regarding stratigraphic position, volume, spatial distribution and up to the use of them as a stratigraphic unit in practical stratigraphy for the construction of geological models. On the basis of microfossils analysis (foraminifers, corals, molluscs, ostracods, bryozoans, polychaeta), ways to solve problem issues are given. Stratigraphic (contain mixed Badenian-Sarmatian complexes, the main signs of diagnosis of which are systematic composition - appearance of Sarmatian elements among the prevailing Badenian; degree of preservation of fossils substitution (primary - carbonate, secondary - phosphatised, limonitized), thickness (thin-walled - transparent, translucent, brittle; thick-walled) and sculpture (ornamentation) walls of skeletons, size of taxa, traces of mechanical damage of remains); biostratigraphic (allocation eco/biozones); paleoecological (appearance/disappearance of skeletons elements, presence of two generation species); paleogeographycal (formation of lithoral in the brackish-water basin) and facial (are the advanced fore-reef facie reef of Medobory Hills) criteria for the identification of Buhliv beds are defined.

\section{REFERENCES}

1. Бугловские слои миочена. Материалы Всесоюзного симпозиума. Львов, 6-16 сентября 1966 г. Киев : Наук. думка, 1970. 279 с.

2. Венглинский И.В., Горецкий В.А. Стратотипы миоценовых отложений Волыно-Подольской плиты, Предкарпатского и Закарпатского прогибов. Киев : Наук. думка, 1979. 176 с.

3. Жирков И.А. Жизнь на дне. Биогеография и биоэкология бентоса. Москва, 2010. 453 с.

4. Кульчицкий Я.О., Кульчицкий А.Я. Двустворчатые и брюхоногие моллюски из сармата Предкарпатского и Закарпатского прогибов и их стратиграфическое значение. Палеонтол. сборник. 1983. № 20. C. $50-58$.

5. Карпенко Н.І. Рельєф морських берегів : навч. посібник. Львів : Видавничий центр ЛНУ імені Івана Франка, 2009. 308 с.

6. Королюк И.К. Подольские Толтры и условия их образования. Труды Ин-та геол. наук АН СССР. Сер. геол. 1952. Вып. 110. № 56.120 с.

7. Ласкарев В.Д. О сарматских отложениях, некоторых мест Волынской губернии. Зап. Новорос. о-ва естествоиспытателей. 1897. № 21. Вып. 2. С. 89-115.

8. Ласкарев В.Д. Фауна бугловских слоев Волыни. СанктПетербург, 1903. 126 с. (Тр. Геол. ком. Нов. сер. Вып. 5). 
9. Максимович Г.А., Быков В.Н. Карст карбонатных нефтегазоносных толщ. Пермский ун-т, 1978.96 с.

10. Маслов В.П. Ископаемые багряные водоросли СССР и их связь с фациями. Изд-во АН СССР. Москва, 1962. 221 с. (Тр. Геологич. ин-та. Вып. 53).

11. Москалюк К.Л. Аналіз рельєфу Подільських Товтр для оптимізації природокористування : автореф. ... канд. географ. наук : 11.00 .04 «Геоморфологія і палеогеографія». Львів, 2009. 23 с.

12. Присяжнюк В. О переходных слоях pp. Ушицы и Ушки В.Д. Ласкарева. Materialete conferintei stiintifice nationale cu participare internationala „,Mediul si Dezvoltarea durabila“. Editia a III-a consacrata aniversarii a 80 ani de la nasterea prof. univ., dr. hab. Alexandru Lungu. 06-08 octombrie 2016. P. 53-56.

13. Приходько М.Г., Пономарьова Л.Д. Гелогічна будова Закарпатського прогину. Монографія. Київ : УкрДГРІ, 2018. 84 с.

14. Рифогенные формации и рифы в эволюции биосферы / Отв. ред. С.В. Рожнов. Серия «Гео-биологические процессы в прошлом». Москва, ПИН РАН, 2011. 228 с.

15.Стратиграфічний кодекс України / Відп. ред. П.Ф. Гожик. 2-е вид. Київ, 2012. 66 с.

16. Тузяк Я. Баденій-сарматська регіональна подія зникнення як критерій для проведення границі в межах Поділля. Розвиток промисловості та суспільства. Секція 5. Геологія та прикладна мінералогія. 22-24 травня 2019 р. Матеріали конференції. Кривий Ріг, 2019. C. 44-48.

17. Тузяк Я. Буглівські верстви (міоцен, неоген) Тернопільської області - комплексна геологічна пам'ятка природи: стан охорони i перспективи рекреаційного використання. Мінерально-сировинні багатства України: иляхи оптимального використання : Матеріали восьмої науково-практичної конференції, 4 жовтня 2019 р. смт Хорошів. Київ, 2019. С. 122-132.

18. Тузяк Я. Границя баденію/сармату (неоген, міоцен): проблеми $\mathrm{i}$ критерії проведення (на прикладі розрізу с. Ванжулів Тернопільської обл.). Актуальні проблеми та перспективи розвитку геології: наука й виробництво. Матеріали VI Міжнародного геологічного форуму, 1722 червня 2019 р., м. Одеса, Україна. Київ : УкрДГРІ, 2019. С. 218-221.

19. Тузяк Я. Подія на границі баденій/сармат в межах Поділля: палеогеографічні та палеоекологічні зміни в Центральному Паратетисі. Здобутки та перспективи розвитку геологічної науки в Украӥні : збірник тез наукової конференції, присвяченої 50-річчю Інституту геохімії, мінералогії та рудоутворення імені М.П. Семененка, Київ, 14-16 травня 2019 р. У 2-х томах. НАН України, Ін-т геохімії, мінералогії та рудоутворення ім. М.П. Семененка. Київ, 2019. Т. 2. C. 229-231. 
20. Тузяк Я. Теоретичні і прикладні аспекти виявлення і проведення геологічних меж в осадово-шаруватих системах. Вісник Львівського університету. Сер. геолог. 2018. Вип. 32. С. 63-83.

21. Шепард Ф.П. Морская геология 3-е изд. Ленинград : Недра, 1976. $488 \mathrm{c}$.

22. Bolli H.M., Saunders J.B. Oligocene to Holocene low latitude planktic foraminifera. Bolli H.M., Saunders J.B., Perch-Nielsen K. (Eds.). Plankton Stratigraphy. Cambridge University Press, Cambridge, 1985. P. 155-262.

23. Boudagher-Fadel M. Biostratigraphical and geological significance of planktonic foraminifera. Updated second edition. UCLPRESS. University College London, 2015. 298 p. DOI: 10.14324/111.9781910634257

24. BouDagher-Fadel M.K. Evolution and Geological Significance of Larger Benthic Foraminifera. Second edition. UCL Press. London, 2018. 693 p. DOI: https://doi.org/10.14324/111.9781911576938

25. Brânzilă M., Chirilă G., Jitaru M. Micropalaeontologic content of the Sarmatian from Southern Moldavian platform - a Backbulge depozone. Acta Palaeontologica Romaniae. 2011. V. 7. P. 45-59.

26. Cicha I., Seneš J. Sur la position du Miocene de la Paratcthys Central dans les cadre du Tertiaire de l'Europe. Geologicky Sbornik. 1968. № 19(1). P. 95-116.

27. De Leeuw A., Filipescu S., Matenco L., Krijgsman W., Kuiper K., Stoica M. Paleomagnetic and chronostratigraphic constraints on the middle to late Miocene evolution of the Transylvanian basin (Romania): Implications for central Paratethys stratigraphy and emplacement of the Tisza-Dacia plate. Global and Planetary Change. 2013. № 103(1). P. 82-98. DOI:10.1016/j.gloplacha.2012.04.008

28. Filipescu S., Silye L. New Paratethyan biozones of planktonic foraminifera described from the Middle Miocene of the Transylvanian Basin (Romania). Geologica Carpathica. December 2008. 59. 6. P. 537-544.

29. Fordinal K., Zágoršek K., Zlinská A. Early Sarmatian biota in the northern part of the Danube Basin (Slovakia). Geologica Carpathica. April 2006. 57. 2. P. 123-130.

30. Gebhardt H., Zorn I., Roetzel R. The initial phase of the early Sarmatian (Middle Miocene) transgression. Foraminiferal and ostracod assemblages from an incised valley fill in the Molasse Basin of Lower Austria. Austrian Journal of Earth Sciences. 2009. Vol. 102/2. P. 100-119.

31. Górka M., Studencka B., Jasionowski M., Hara U., Wysocka A., Poberezhskyy A. The Medobory Hills (Ukraine): Middle Miocene Reef Systems in the Parathetys, their biological diversity and lithofacies. Biuletyn Państwowego Instytutu Geologicznego. 2012. № 449. P. 147-174.

32. Hara U., Jasionowski M. The Early Sarmatian bryozoan Celleporina medoborensis sp. nov. from the Medobory reefs of west ern Ukraine (Central Paratethys). Geological Quarterly. 2012. №56 (4). P. 895-906. 
33. Harzhauser M., Piller W.E. Integrated stratigraphy of the Sarmatian (Upper Middle Miocene) in the western Central Paratethys. Stratigraphy. 2004. № 1(1). 65-86.

34. Hayward B.W., Le Coze F., Vachard D., Gross O. World Foraminifera Database. 2019. URL: http://www.marinespecies.org/ aphia.php? $\mathrm{p}=$ taxdetails\&id $=113497$ on 2019-11-10.

35. Hohenegger J., Rögl F., Coric S., Pervesler P., Lirer F., Roetzel R., Scholger R., Stingl K. The Styrian Basin: A key to the Middle Miocene (Badenian/Langhian) Central Paratethys transgressions. Austrian Journal of Earth Sciences. 2009. № 102(1). P. 102-132.

36. Hohenegger J., Ćorić S., Wagreich M. Timing of the Middle Miocene Badenian Stage of the Central Paratethys. Geologica Carpathica, February 2014. № 65. 1. P. 55-66. DOI: 10.2478/geoca-2014-0004

37. Lirer F. et al. Astronomically forced teleconnection between Paratethyan and Mediterranean sediments during the Middle and Late Miocene. Palaeogeography, Palaeoclimatology, Palaeoecology. 2009. № 275(1-4). P. 1-13. DOI10.1016/j.palaeo.2009.01.006

38. Palcu D.V., Tulbure M., Bartol M., Kouwenhoven T.J., Krijgsman W. The Badenian-Sarmatian Extinction Event in the Carpathian foredeep basin of Romania: paleogeographic changes in the Paratethys domain. Global and Planetary Change. 2015. 36 p. DOI: 10.1016/ j.gloplacha.2015.08.01

39. Papp A. et al. Zur Nomenklatur des Neogens in Österreich. Verh. Geol. Bundesanst. 1968. P. 9-27.

40. Paulissen W., Luthi S., Grunert P., Coric S., Harzhauser M. Integrated high-resolution stratigraphy of a Middle to Late Miocene sedimentary sequence in the central part of the Vienna Basin. Geologica Carpathica. 2011. № 62(2). P. 155-169. DOI: 10.2478/v10096-011-0013-z

41. Peryt D., Jasionowski M. Sarmatian foraminiferal assemblages of cavern fillings in the Badenian reefs of Medobory (Polupaniwka, Western Ukraine). Biuletyn Państwowego Instytutu Geologicznego. 2012. № 449. P. 175-184.

42. Piller W.E, Harzhauser M. The myth of the brackish Sarmatian Sea. Terra Nova. 2005. № $17 . \quad$ P. 450-455. DOI: 10.1111/j.13653121.2005.00632.x

43. Popov S.V., Shcherba I., Ilyina L., Nevesskaya L., Paramonova N., Khondkarian S., Magyar I. Late Miocene to Pliocene palaeogeography of the Paratethys and its relation to the Mediterranean. Palaeogeography, Palaeoclimatology, Palaeoecology. 2006. № 238 (1-4). P. 91-106. DOI: 10.1016/j.palaeo.2006.03.020

44. Popov S.V. et al. Eastern Paratethys stratigraphic scale of Neogene: correlation possibilities. Abstr. 14th RCMNS congress. 8-12 September 2013, Istanbul (Turkey).

45. Rögl F., Spezzaferri S. Foraminiferal paleoecology and biostratigraphy of the Mühlbach section (Gaindorf Formation, Lower 
Badenian), Lower Austria. Ann. Naturhist. Mus. Wien. Mai. 2003. № 104. P. 23-75.

46. Rögl F., Steininger F.F. Vom Zerfall der Tethys zu Mediterran und Paratethys. Die Neogene Palaeogeographie und Palinspastik des zirkummediterranen Raumes. Annales Naturhistorischen Museum Wien. 1983. № 85. P. 135-163.

47. Selmeczi I., Lantos M., Bohn-Havas M., Nagymarosy A., Szegö E. Correlation of bio- and magnetostratigraphy of Badenian sequences from western and northern Hungary. Geologica Carpathica. 2012. № 63(3). P. 219-232. DOI: https://doi.org/10.2478/v10096-012-0019-1

48. Senes J. Paläogeographie des Westkarpatischen Raumes in Beziehung zur übrigen Paratethys im Miozän.Geologické Práce. 1961. № 60. P. 1-56.

49. Szczechura J. Palaeoenvironments of the Middle Miocene evaporitebearing deposits from the Działoszyce Trough, Carpathian Foredeep, Poland, based on microfaunal studies. Gcol. Quart. 2000. № 44 (2). P. 119-135.

50. Wiens H.J. Atoll environment and ecology. L.: Yale University Press, $1962.532 \mathrm{p}$.

51. Westerhold T., Torsten B., Röhl U. Middle to late Miocene oxygen isotope stratigraphy of ODP site 1085 (SE Atlantic): new constrains on Miocene climate variability and sea-level fluctuations. Palaeogeography, Palaeoclimatology, Palaeoecology. 2005. № 217(3-4). P. 205-222. DOI: org/10.1016/j.palaeo.2004.12.001

52. Vrsaljko D., Pavelić D., Miknić M., Brkic M., Kovacic M., Hećimović I., Hajek-Tadesse V., Avanić R., Kurtanjek N. Middle Miocene (Upper Badenian/Sarmatian) Palaeoecology and Evolution of the Environments in the Area of Medvednica Mt. (North Croatia). Geologia Croatica. Zagreb. 2006. № 59/1. P. 51-63.

53. Wysocka A., Radwanski A., Gorka M., Babel M., Radwanska U., Zlotnik M. The Middle Miocene of the Fore-Carpathian Basin (Poland, Ukraine and Moldova). Acta Geologica Polonica. 2016. Vol. 66. No. 3. P. 351-401. DOI: 10.1515/agp-2016-0017

54. Chapter 15 Animals of the benthic environment. URL: https://slideplayer.com/slide/4022004/.

Information about author: Tuzyak Ya. M., Candidate of Geological Sciences, Senior Laboratory Assistant of the Department of General and Historical Geology and Paleontology Ivan Franko National University of Lviv 1, Universytetska str., Lviv, 79001, Ukraine 